Article

\title{
Temporal Variability of Source-Specific Solvent-Extractable Organic Compounds in Coastal Aerosols over Xiamen, China
}

\author{
Shuqin Tao ${ }^{1,2, *}$, Xijie Yin ${ }^{3}$, Liping Jiao ${ }^{1}$, Shuhui Zhao ${ }^{1}$ and Liqi Chen ${ }^{1,2, *}$ \\ 1 Key Laboratory of Global Change and Marine-Atmospheric Chemistry of State Oceanic \\ Administration (SOA), Third Institute of Oceanography, State Oceanic Administration (SOA), \\ Xiamen 361005, China; jiaoliping@tio.org.cn (L.J.); shzhao@tio.org.cn (S.Z.) \\ 2 College of Ocean and Earth Sciences, Xiamen University, Xiamen 361008, China \\ 3 Laboratory of Marine and Coastal Geology, Third Institute of Oceanography, \\ State Oceanic Administration (SOA), Xiamen 361005, China; yinxijie@tio.org.cn \\ * Correspondence: taoshuqin@tio.org.cn (S.T.); Chenliqi@tio.org.cn (L.C.); \\ Tel.: +86-592-219-5991 (S.T.); +86-592-219-5353 (L.C.)
}

Academic Editor: Robert W. Talbot

Received: 21 November 2016; Accepted: 4 February 2017; Published: 8 February 2017

\begin{abstract}
This study describes an analysis of ambient aerosols in a southeastern coastal city of China (Xiamen) in order to assess the temporal variability in the concentrations and sources of organic aerosols (OA). Molecular-level measurements based on a series of solvent extractable lipid compounds reveal inherent heterogeneity in $\mathrm{OA}$, in which the concentration and relative contribution of at least three distinct components (terrestrial plant wax derived, marine/microbial and fossil fuel derived organic matter (OM)) exhibited distinct and systematic temporal variability. Plant wax lipids and associated terrestrial $\mathrm{OM}$ are influenced by seasonal variability in plant growth; marine/microbial lipids and associated marine $\mathrm{OM}$ are modulated by sea spill and temperature change, whereas fossil fuel derived OM reflects the anthropogenic utilization of fossil fuels originated from petroleum-derived sources and its temporal variation is strongly controlled by meteorological conditions (e.g., the thermal inversion layer), which is analogous to other air organic pollutions. A comparative study among different coastal cities was applied to estimate the supply of different sources of $\mathrm{OM}$ to ambient aerosols in different regions, where it was found that biogenic OM in aerosols over Xiamen was much lower than that of other cities; however, petroleum-derived OM exhibited a high level of contribution with a higher concentration of unresolved complex matters (UCM) and higher a ratio between UCM and resolved alkanes (UCM/R).
\end{abstract}

Keywords: temporal variability; organic aerosols $(\mathrm{OA})$; source-specific lipids; marine and microbial $\mathrm{OM}$; plant wax OM; fossil fuel-derived OM; coastal cities; Xiamen

\section{Introduction}

Air particulate pollution resulting from ambient aerosols has long been recognized as a serious nation-wide problem in China. Recently, Asian dust episodes have become more frequent and intensive, thereby spurring unprecedented political attention locally and internationally. Severe air particulate pollution not only causes a reduction in visibility, but also create adverse effects on human health, with the organic matter $(\mathrm{OM})$ in the aerosols partly to blame for these health problems [1]. Organic aerosols (OA) are a major constituent of ambient aerosols, accounting for $20 \%-90 \%$ by mass [2-4]. Therefore, solvent-extractable organic matters (SOM), also known as lipid compounds (e.g., $n$-alkanes, $n$-alkanols and polycyclic aromatic hydrocarbons (PAHs)), have been found to be cytotoxic and to cause DNA lesions even at non-toxic dosages [1]. In addition, the degree of cytotoxicity of these SOM have been 
proved to correlate to their compositions and amount in the ambient air [1]. Thus, constraining the chemical composition, amount and residence time of SOM in ambient aerosols would provide a better understanding of the potential toxicity of particulate air pollution in terms of OM.

Additionally, SOM in aerosols contain a series of useful source-specific lipid biomarkers which have been successfully used for source appointment [5-10]. For organic aerosols, natural biogenic lipids are organic compounds from a marine primary source via bubble bursting processes [11,12], microorganism and terrestrial plant wax. Anthropogenic sources mostly derive from the combustion processes of fossil fuel and vehicle exhaust. Therefore, source-specific lipid biomarkers are powerful tracer of the sources and processes acting upon simultaneous aerosol particles [5-8,13,14], which inherit biogeochemical characteristics of their organic precursors due to chemical stability and source specificity. Thus, the comprehensive analysis of source-specific lipids associated with carbon-containing aerosol particles would provide a more detailed insight into a discriminating assessment of various biogenic and human impacts on the lower tropospheric environment.

The lower troposphere is an open, active and short-term reservoir for OA. In addition to multiple source impact, an association with particle size, transportation processes and meteorological change all exert strong influences on their distributions and physiochemical properties. These complex patterns of supply and dispersal make it challenging when assessing controls on the biogeochemical cycle of OA. Still, great efforts have been made in understanding the composition, sources, and transport of OA $[4-7,9,10,15-19]$. As variation in these biogeochemical characteristics of OA are very high depending on the location and season, they are also influenced by marked spatial/temporal variability in the provenance of aerosol supply and meteorological conditions $[4,20]$. In this study, the coastal city of Xiamen was examined in order to investigate temporal variations in the composition and sources of $\mathrm{OA}$ as a function of meteorological conditions and human activities based on source-specific lipid biomarker tools. In total, 12 one-month time-integrated samples (collected from May 2015 to April 2016) were used to (1) obtain loadings and relevant biogeochemical implications of the solvent extractable lipids for hydrocarbons, $n$-fatty acids ( $n$-FAs) and $n$-alkanols; (2) evaluate temporal variability in relative OA contributions from marine, microbial, terrestrial plant and fossil fuel origins; and (3) identify processes responsible for these variations.

Xiamen is a coastal tourist city situated in the southeast of China $\left(24.44^{\circ} \mathrm{N}\right.$ and $\left.118.09^{\circ} \mathrm{E}\right)$ with an area of $158 \mathrm{~km}^{2}$ and a population of 1.86 million (2010), and was one of the cleanest coastal cities in China for air quality [21]. It exhibit a distinct seasonal variation in climate, which is modulated by the East Asian Monsoon system. However, due to rapid urbanization and an increasingly busy port shipping, the air quality of Xiamen has gradually deteriorated to the point where hazy days have increased by approximately six-fold from 2003 to 2008 [22]. Within this framework of increasingly anthropogenic influences, the careful evaluation of anthropogenic influences is a prerequisite for understanding anthropogenic signal superimposed on the natural background of biogenic aerosols. Such assessments may also serve as an important reference point for predicting future trend for coastal aerosol systems under increasing human perturbations.

\section{Experimental Methods}

\subsection{Aerosol Samples, Collections and Preparations}

Aerosol samples of approximately one gram were collected using a high-volume sampler model HYSS-5001 at the Observatory. The supply for local ambient aerosols is regarded as a mixture of marine and continental materials. A total of 12 one-month time-integrated samples, collected from May 2015 to April 2016, were used to analyze lipid biomarkers in the ambient air. Aerosol samples were collected on pre-combusted $\left(4 \mathrm{~h}, 450^{\circ} \mathrm{C}\right)$ Munktell micro-quartz fiber filters. The flow rate was $0.6-0.9 \mathrm{~m}^{3} / \mathrm{min}$ and the sampling time was $24-31$ days for each sample to acquire sufficient aerosol particulates for analysis and to gather information on the variations over the entire month. These simultaneously yielded total suspended particulate (TSP) samples were stored in pre-combusted (4 h, 
$450{ }^{\circ} \mathrm{C}$ ) aluminum foils at $-20^{\circ} \mathrm{C}$ to prevent microbial contamination. The filters were freeze-dried immediately afterwards, and the TSP concentration was determined based on the weight of particles on the filters and the volume of filtered air obtained from the flowmeter.

\subsection{Bulk Analysis}

A small aliquot of freeze-dried TSP samples was exposed to $12 \mathrm{M} \mathrm{HCl}$ vapors in order to remove inorganic carbon [23], and subsequently used for total organic carbon (TOC) and bulk $\delta^{13} \mathrm{C}$ analysis at the Stable Isotope Facility (Flash HT, Delta V Advantage) within the Scientific Instruments Sharing Service Platform of Third Institute of Oceanography, SOA (TIO-SOA, Xiamen, China), with a standard deviation of $0.002 \mathrm{wt} \%(n=6)$ and $0.1 \% 0(n=6)$, respectively.

\subsection{Lipid Isolation and Analysis}

Deuterium-substituted $n$-C24 alkane, $n$-C19 alkanol and n-C19 FA were added as internal standards to the freeze-dried samples (0.7-1.8 g), which were then extracted four times ultrasonically with a 9:1 mixture of dichloromethane (DCM) and methanol (MeOH). The combined extract was dried under $\mathrm{N}_{2}$ and then saponified $(0.5 \mathrm{M} \mathrm{KOH}$ in $\mathrm{MeOH}, 15 \mathrm{~mL}$, with a few drops of Milli-Q water, $70{ }^{\circ} \mathrm{C}, 2 \mathrm{~h}$ ). After hydrolysis, $10 \mathrm{~mL}$ Milli-Q water was added and a "neutral" fraction was obtained by liquid-liquid extraction with hexane $(10 \mathrm{~mL} \times 3)$. The aqueous layer was subsequently adjusted to $\mathrm{pH} 1$ using $12 \mathrm{M} \mathrm{HCl}$, and an "acid" fraction was obtained with a mixture of hexane and DCM $(4: 1 \mathrm{v} / \mathrm{v}, 3 \times 10 \mathrm{~mL})$. This acid fraction containing the FAs was transesterified to yield the corresponding FA methyl esters (FAMEs) with a mixture of $\mathrm{HCl}$ and $\mathrm{MeOH}(5: 95 \mathrm{v} / \mathrm{v}, 10 \mathrm{~mL}$, $70{ }^{\circ} \mathrm{C}$ for $12 \mathrm{~h}$ ). The resulting FAMEs were recovered by liquid-liquid extraction with hexane $(3 \times 10 \mathrm{~mL})$. The FAMEs fraction was further separated by liquid chromatography on a Pasteur pipette column $(6 \mathrm{~mm}$ i.d. $\times 4 \mathrm{~cm})$ filled with $\mathrm{AgNO}_{3}$-impregnated silica gel $(\sim 10 \% \mathrm{w} / \mathrm{w})$ to separate saturated $n$-FAMEs and unsaturated homologues eluted with $4 \mathrm{~mL}$ hexane/DCM $(1: 2 \mathrm{v} / \mathrm{v})$ and $4 \mathrm{~mL}$ $\mathrm{DCM} / \mathrm{MeOH}(95: 5 \mathrm{v} / \mathrm{v})$. The "neutral" fraction was further separated by liquid chromatography on a Pasteur pipette column $(6 \mathrm{~mm}$ i.d. $\times 4 \mathrm{~cm})$ filled with one percent deactivated silica gel. The "neutral" fraction was further separated into two fractions-F1 (hydrocarbons) and F2 (alkanols) by elution with hexane $(4 \mathrm{~mL})$, and $\mathrm{DCM} / \mathrm{MeOH}(95: 5 \mathrm{v} / \mathrm{v}, 4 \mathrm{~mL})$, respectively. $n$-Alkanols were derivated with $\mathrm{N}, \mathrm{O}-\mathrm{bis}$ (trimethylsilyl)-trifluoroacetamide (BSTFA) in DCM $\left(70{ }^{\circ} \mathrm{C}, 1 \mathrm{~h}\right)$.

For quantification, a small aliquot (typically $1 / 500$ ) of each hydrocarbon, BSTFA derivated alkanol, and $n$-FAME was injected on a thermal 1300 series gas chromatograph (GC) equipped with flame ionization detector (FID) and a DB-5ms capillary column ( $60 \mathrm{~m} \times 0.25 \mathrm{~mm}$ i.d., $0.25 \mu \mathrm{m}$ film thickness) with nitrogen as the carrier gas at a flow rate of $1.5 \mathrm{~mL} / \mathrm{min}$. Both the injector and detector were set at $300^{\circ} \mathrm{C}$. For the hydrocarbon fraction, the oven was kept initially at $80^{\circ} \mathrm{C}$ for $1 \mathrm{~min}$, and then programmed to $200{ }^{\circ} \mathrm{C}$ at $25^{\circ} \mathrm{C} / \mathrm{min}$, followed by $1.5^{\circ} \mathrm{C} / \mathrm{min}$ to $230^{\circ} \mathrm{C}, 2^{\circ} \mathrm{C} / \mathrm{min}$ to $250{ }^{\circ} \mathrm{C}, 5^{\circ} \mathrm{C} / \mathrm{min}$ to $300{ }^{\circ} \mathrm{C}$ (holding for $10 \mathrm{~min}$ ) and finally $5{ }^{\circ} \mathrm{C} / \mathrm{min}$ to $310{ }^{\circ} \mathrm{C}$ (holding for $20 \mathrm{~min}$ ). For the $n$-FA fraction, the oven was kept initially at $80^{\circ} \mathrm{C}$ for $1 \mathrm{~min}$, and then programmed to $180^{\circ} \mathrm{C}$ at $25^{\circ} \mathrm{C} / \mathrm{min}$, followed by $2{ }^{\circ} \mathrm{C} / \mathrm{min}$ to $300{ }^{\circ} \mathrm{C}$ (holding for $5 \mathrm{~min}$ ), and finally $5{ }^{\circ} \mathrm{C} / \mathrm{min}$ to $310^{\circ} \mathrm{C}$ (holding for $20 \mathrm{~min}$ ). For the alkanol fraction, the oven was kept initially at $80^{\circ} \mathrm{C}$ for $1 \mathrm{~min}$, and then programmed to $200{ }^{\circ} \mathrm{C}$ at $25^{\circ} \mathrm{C} / \mathrm{min}$, followed by $4{ }^{\circ} \mathrm{C} / \mathrm{min}$ to $250{ }^{\circ} \mathrm{C}, 1.5^{\circ} \mathrm{C} / \mathrm{min}$ to $300{ }^{\circ} \mathrm{C}$ (holding for $20 \mathrm{~min}$ ), and finally $5{ }^{\circ} \mathrm{C} / \mathrm{min}$ to $310^{\circ} \mathrm{C}$ (holding for $15 \mathrm{~min}$ ). Qualitative and quantitative determination was achieved by comparing GC-FID retention time and signal intensity of the sample and that of a known amount of a hydrocarbon, BSTFA derivated alkanol and $n$-FAME standard under the same conditions. Standard mixtures of $\mathrm{C}_{8}-\mathrm{C}_{40} n$-alkanes with $50 \mathrm{ng} / \mu \mathrm{L}$ were measured every 15 injections to evaluate GC-FID analytical uncertainty within the relative standard deviation of $20 \%$.

\subsection{Statistical Methods}

In this study, the content and stable carbon isotopes of multiple compounds were determined. In order to avoid repetitive discussion, the Hierarchical Cluster Analysis was used to classify various 
compounds into groups according to similarity of molecular characteristics (content), and the Pearson correlation coefficient $\left(R^{2}\right)$ measured the similarities between variables. The concentration matrix was standardized using the Z-score as follows:

$$
Z_{i j}=\frac{X_{i j}-\overline{X_{i}}}{\sigma_{i}}
$$

where $X_{i j}$ is the concentration of the $i$-homolog on the j-sample, and $\overline{X_{i}}$ and $\sigma_{i}$ are the mean and standard deviation of the $i$-homolog, respectively. For this application, the content and matrixes $(X(n \times m))$ with $n$-rows (the number of homologs) and $m$-columns (the number of samples analyzed) was constructed. The $\mathrm{R}^{2}$ was used as a measure of the similarities between the variables. The number and the structure of clusters formed using these methods are not affected with either the addition of small numbers of "bad" points or the use of a limited number of measurements.

\section{Results}

A series of solvent extractable source-specific lipids were determined in 12 TSP aerosol samples collected from May 2015 to April 2016 in order to better characterize seasonal variations in the different organic components (marine and microbial, terrestrial plant and petroleum-derived $\mathrm{OM}$ ) of the ambient aerosols in sub-tropical monsoon-influenced coastal area, using Xiamen city as a typical example. As the second cleanest city for air quality [21] and one of top ten Chinese port cities, Xiamen was a suitable place to study the natural background of biogenic OA, as well to monitor the interruption of petroleum-derived organic aerosol due to a huge amount caused by shipping and the port. Topographically, Xiamen is located down wind of the origin (e.g., Hebei Province) of the Chinese haze in the winter and spring when northwesterly winds prevail. Thus, it is an important exit point of the Chinese haze to the West Pacific.

\subsection{Meteorological Characteristics}

Daily and monthly meteorological characteristics, such as air temperature, relative humidity, rain accumulation, and wind speed and direction in Xiamen during the period from May 2015 to April 2016 (Supplementary Figure S1) were monitored by an automatic weather station WXT520 (Vaisala, Vantaa, Finland), which was co-located with the high-volume sampler (HYSS-5001) at a Marine Atmospheric Environmental Observatory on the roof of the building approximately $45 \mathrm{~m}$ above sea level and $\sim 10 \mathrm{~m}$ ground distance to the high tide level. The air temperature was highest in summer (June-August; average $28.2-28.4^{\circ} \mathrm{C}$ ) and lower in winter (January-March; average 12.8-14.5 ${ }^{\circ} \mathrm{C}$ ), while spring (April-May; average, $20.1-24.0^{\circ} \mathrm{C}$ ) and fall (September-November; average $22.4-26.7^{\circ} \mathrm{C}$ ) were considered transitional seasons in Xiamen (Supplementary Figure S1a). With regard to air humidity, the monthly average relative humidity varied from $60 \%$ to $80 \%$. The formation of a thermal inversion layer in winter inhibited heat exchange and material diffusion, which resulted in enhanced moisture shown clearly in January (Supplementary Figure S1b). Higher humidity also occurred during spring, which coincided with the rainy season from April to May (Supplementary Figure S1b). For rain accumulation, the highest value occurred in August, and higher value also occurred during spring (Supplementary Figure S1c), which coincided with high precipitation during typhoon season (with the strongest typhoon effect occurring in August 2015) and the spring rain. With regard to wind information, the south (SE-S-SW) wind from the sea was prevalent in early summer (June-July), but there was no prevalent wind direction in August when high-frequent and intensive typhoon events complicated the wind monitoring system. However, the north wind (N-NE) from the land dominated in the fall and winter months (September-March). With an increase in air temperature, the east wind (NE-E-SE) was popular in spring (Figure 1). Generally, wind speed showed a distinct seasonal cycle. After summer, the monthly average wind speed gradually increased and peaked in late fall (October), before decreasing during the winter period with the lowest speed in spring (Supplementary Figure S1d). 


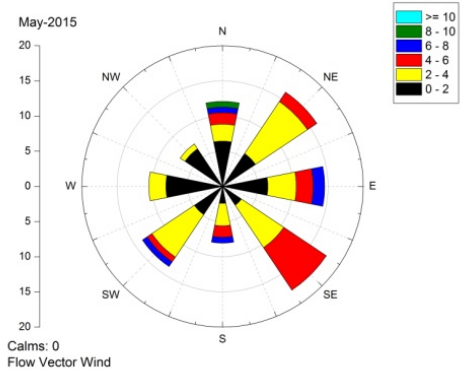

(a) May 2015

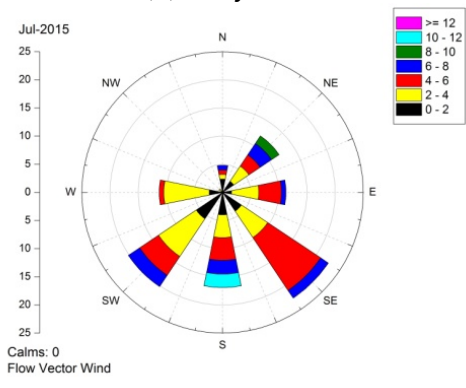

(c) July 2015

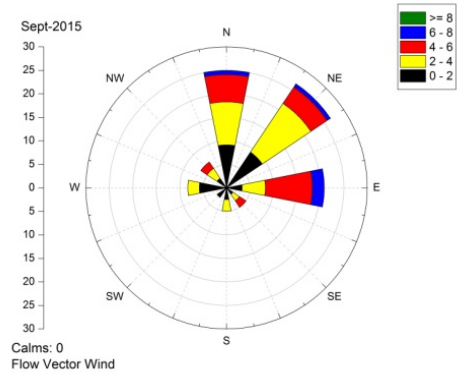

(e) September 2015

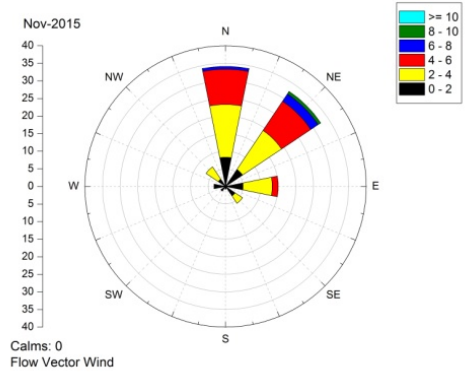

(g) November 2015

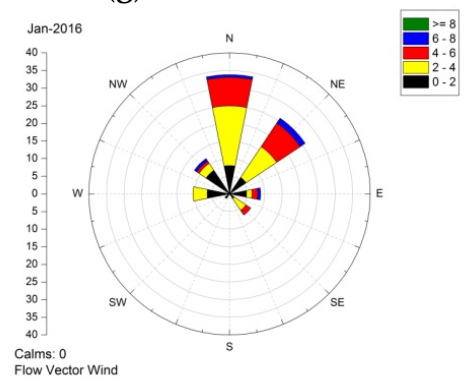

(i) January 2016

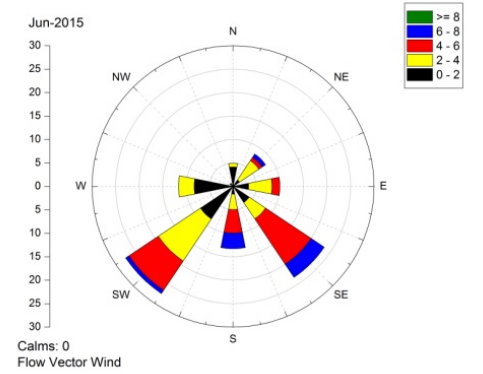

(b) June 2015

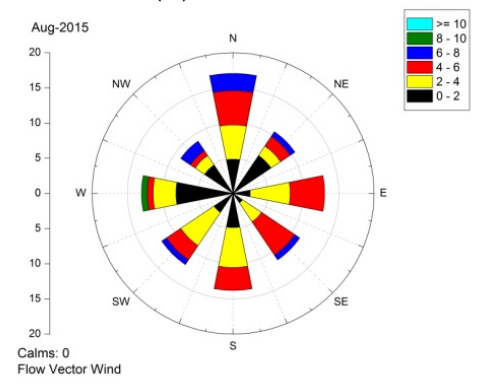

(d) August 2015

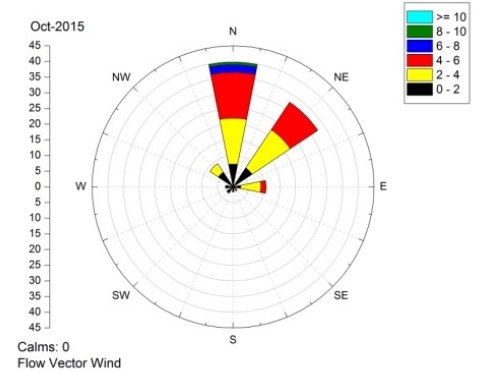

(f) October 2015

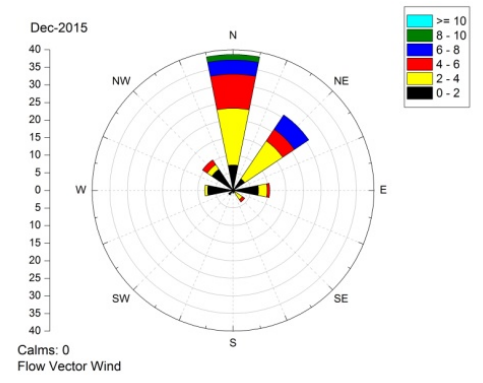

(h) December 2015

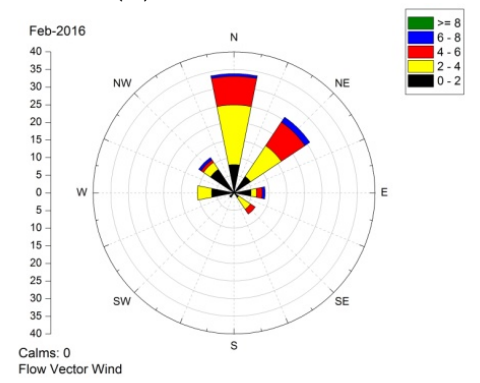

(j) February 2016

Figure 1. Cont. 


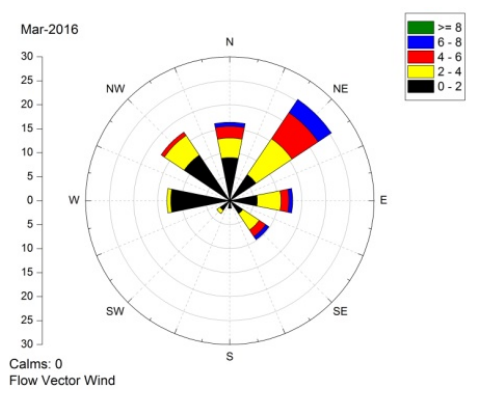

(k) March 2016

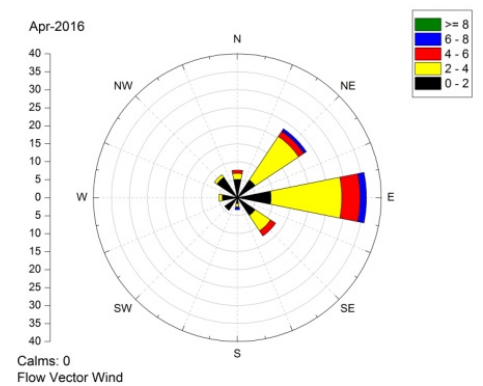

(1) April 2016

Figure 1. Six-hour wind direction variations in Xiamen during the period from May 2015 to April 2016. (a) May 2015; (b) June 2015; (c) July 2015; (d) August 2015; (e) September 2015; (f) October 2015; (g) November 2015; (h) December 2015; (i) January 2016; (j) February 2016; (k) March 2016; (1) April 2016.

\subsection{TSP and Bulk OC Yeilds}

Ambient aerosols collected over Xiamen yielded TSP concentrations of $27.4-84.1 \mu \mathrm{g} / \mathrm{m}^{3}$, TOC contents of 9.6-23.7 wt \%, concentrations of 3.67 and $11.97 \mu \mathrm{g} / \mathrm{m}^{3}$ and stable carbon isotopic compositions of TOC $\left(\delta^{13} \mathrm{C}_{\mathrm{TOC}}\right)$ of -25.2 to $-27.0 \%$ (Table 1$)$. TSP and TOC concentrations generally displayed similar seasonal variability, with lower values in warm seasons (summer and early fall) and higher values in cool seasons (winter and early spring) (Figure 2a). TOC contents exhibited a single peak in fall, and lower values during the remaining times of the year. $\delta^{13} \mathrm{C}$ of TOC showed relatively high values during the period of summer and fall, and a second peak in late winter (February and March).

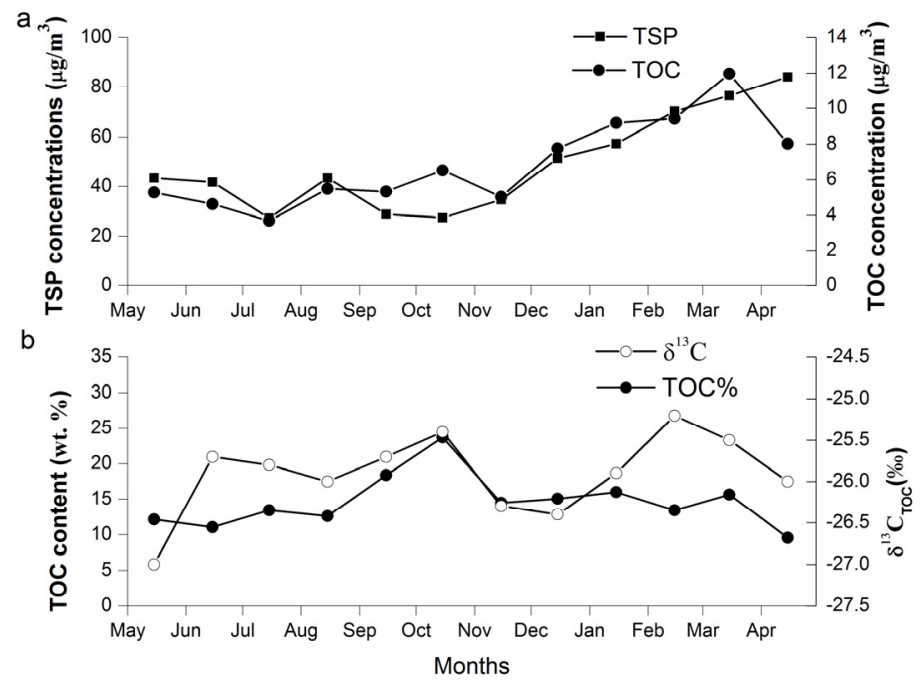

Figure 2. Temporal variations in bulk characteristics of ambient air aerosols in south coastal Xiamen. (a) Total suspended particulate (TSP) and total organic carbon (TOC) concentrations; (b) TOC contents (dry weight relative to TSP) and their stable carbon isotopic composition. 
Table 1. Summary of yields and important proxies of the hydrocarbon, $n$-FA and alkanol fractions in ambient aerosols, collected in Xiamen, China.

\begin{tabular}{|c|c|c|c|c|c|c|c|c|c|c|c|c|c|c|c|c|c|c|c|c|}
\hline \multirow{2}{*}{$\begin{array}{l}\text { Sampling } \\
\text { Time }\end{array}$} & \multirow{2}{*}{$\begin{array}{c}\text { TSP } \\
\begin{array}{c}\text { Yield } \\
\mu \mathrm{g} / \mathrm{m}^{3}\end{array}\end{array}$} & \multicolumn{3}{|c|}{ TOC } & \multicolumn{5}{|c|}{$n$-Alkanes } & \multicolumn{2}{|c|}{$\mathrm{UCM}^{1}$} & \multicolumn{6}{|c|}{$n$-FAs } & \multicolumn{3}{|c|}{ Alkanols } \\
\hline & & $\begin{array}{c}\text { Yield } \\
\mu \mathrm{g} / \mathrm{m}^{3}\end{array}$ & $\begin{array}{c}\text { Content } \\
\text { wt } \%\end{array}$ & $\begin{array}{c}\delta^{{ }^{13} \mathrm{C}_{\mathrm{TOC}}} \\
\%\end{array}$ & $\begin{array}{l}\text { Yield } \\
\mathrm{ng} / \mathrm{m}^{3}\end{array}$ & $\mathrm{CPI}_{\Sigma 15-36}$ & $\mathrm{CPI}_{\Sigma 21-26}$ & $\mathrm{CPI}_{\Sigma 29-36}$ & $\mathrm{C}_{\max }$ & $\begin{array}{l}\text { Yield } \\
\mathrm{ng} / \mathrm{m}^{3}\end{array}$ & $\mathrm{U} / \mathrm{R}$ & $\begin{array}{l}\text { Yield } \\
\mathbf{n g} / \mathbf{m}^{3}\end{array}$ & $\mathrm{CPI}_{\Sigma 12-32}$ & $\mathrm{CPI}_{\Sigma 22-32}$ & $\mathrm{C}_{\max }$ & Unsaturated & $C_{18: 1} / C_{18: 0}$ & $\begin{array}{l}\text { Yield } \\
\mathrm{ng} / \mathrm{m}^{3}\end{array}$ & $\mathrm{CPI}_{\Sigma 22-32}$ & $\mathrm{C}_{\max }$ \\
\hline May 2015 & 43.5 & 5.28 & 12.1 & -27.0 & 23.1 & 1.7 & 0.6 & 2.4 & $\mathrm{C}_{31}$ & 156.9 & 5.9 & 70.4 & 28.6 & 3.9 & $C_{16}$ & 5.6 & 0.34 & 13.6 & 10.9 & $\mathrm{C}_{28}$ \\
\hline Jun. 2015 & 41.8 & 4.62 & 11.1 & -25.7 & 16.1 & 1.8 & 0.7 & 2.3 & $\mathrm{C}_{31}$ & 95.6 & 5.0 & 58.0 & 23.2 & 3.9 & $\mathrm{C}_{16}$ & 5.7 & 0.42 & 11.3 & 11.1 & $\mathrm{C}_{28}$ \\
\hline Jul. 2015 & 27.4 & 3.67 & 13.4 & -25.8 & 15.9 & 2.0 & 0.7 & 2.5 & $\mathrm{C}_{31}$ & 80.1 & 4.3 & 51.9 & 20.2 & 4.1 & $\mathrm{C}_{16}$ & 9.6 & 1.01 & 14.2 & 11.3 & $\mathrm{C}_{30}$ \\
\hline Aug. 2015 & 43.5 & 5.48 & 12.6 & -26.0 & 17.2 & 1.9 & 0.6 & 2.5 & $\mathrm{C}_{31}$ & 120.0 & 5.9 & 69.7 & 26.3 & 4.2 & $\mathrm{C}_{16}$ & 10.3 & 0.71 & 14.3 & 11.8 & $\mathrm{C}_{30}$ \\
\hline Sept. 2015 & 28.9 & 5.32 & 18.4 & -25.7 & 23.1 & 1.9 & 0.8 & 2.5 & $C_{31}$ & 85.1 & 3.2 & 59.1 & 21.0 & 3.8 & $\mathrm{C}_{16}$ & 6.9 & 0.57 & 22.1 & 11.6 & $\mathrm{C}_{28}$ \\
\hline Oct. 2015 & 27.6 & 6.53 & 23.7 & -25.4 & 30.6 & 2.0 & 0.5 & 2.8 & $\mathrm{C}_{29}$ & 126.5 & 3.6 & 53.3 & 16.9 & 3.4 & $\mathrm{C}_{16}$ & 4.8 & 0.41 & 22.5 & 8.3 & $\mathrm{C}_{28}$ \\
\hline Nov. 2015 & 34.7 & 5.03 & 14.5 & -26.3 & 37.3 & 1.6 & 0.7 & 2.3 & $\mathrm{C}_{29}$ & 247.9 & 5.9 & 57.3 & 19.0 & 3.3 & $\mathrm{C}_{16}$ & 3.9 & 0.27 & 17.4 & 10.6 & $\mathrm{C}_{28}$ \\
\hline Dec. 2015 & 51.6 & 7.77 & 15.1 & -26.4 & 48.4 & 1.5 & 0.7 & 2.6 & $\mathrm{C}_{29}$ & 295.7 & 5.6 & 73.5 & 21.5 & 3.2 & $\mathrm{C}_{16}$ & 5.3 & 0.25 & 23.2 & 9.9 & $\mathrm{C}_{28}$ \\
\hline Jan. 2016 & 57.4 & 9.20 & 16.0 & -25.9 & 45.9 & 1.3 & 0.8 & 2.1 & $\mathrm{C}_{29}$ & 285.0 & 5.8 & 68.2 & 21.6 & 3.1 & $\mathrm{C}_{16}$ & 4.8 & 0.25 & 20.7 & 9.2 & $\mathrm{C}_{28}$ \\
\hline Feb. 2016 & 70.2 & 9.43 & 13.4 & -25.2 & 53.7 & 1.6 & 0.8 & 2.5 & $\mathrm{C}_{31}$ & 201.5 & 3.4 & 61.0 & 13.7 & 3.0 & $\mathrm{C}_{16}$ & 3.5 & 0.22 & 25.8 & 8.3 & $\mathrm{C}_{28}$ \\
\hline Mar. 2016 & 76.5 & 11.97 & 15.6 & -25.5 & 61.8 & 1.5 & 0.7 & 2.4 & $C_{31}$ & 398.3 & 5.9 & 86.8 & 18.6 & 3.0 & $\mathrm{C}_{16}$ & 6.5 & 0.27 & 35.1 & 15.5 & $\mathrm{C}_{28}$ \\
\hline Apr. 2016 & 84.1 & 8.04 & 9.6 & -26.0 & 34.0 & 1.6 & 0.6 & 2.4 & $\mathrm{C}_{31}$ & 321.3 & 8.5 & 91.6 & 25.9 & 3.6 & $\mathrm{C}_{16}$ & 8.1 & 0.38 & 19.5 & 10.7 & $\mathrm{C}_{28}$ \\
\hline
\end{tabular}

${ }^{1}$ UCM refers to the unresolved comlex mixture of branched and cyclic hydrocarbons, shown as a hump under the baseline of resolved $n$-alkanes in GC chromatogram of the hydrocarbon

fraction in each sample. The abundant UCM is characteristic of weathered petroleum. Quantification is achieved by comparing GC-FID signals of the UCM hump and that of a known

amount of $n-\mathrm{C}_{24}$ deuterated alkane internal standard under the same conditions. The standard deviations of TOC content and its $\delta^{13} \mathrm{C}$ values are $0.002 \mathrm{wt} \%$ and $0.1 \%$, respectively.

The analytical uncertainties (relatively standard deviation) in abundances of lipid biomarkers are within $20 \%$ 


\subsection{Various Lipid Biomarker Yields}

\subsubsection{Hydrocarbons}

Hydrocarbons of ambient aerosols over Xiamen mainly consisted of two groups: $n$-alkanes and UCM. UCM refers to the unresolved complex mixture of branched and cyclic hydrocarbons, shown as a hump under the baseline of resolved $n$-alkanes in the GC chromatogram of the total hydrocarbon fraction in each sample. $C_{15}$ to $C_{36} n$-alkanes were determined, and typical distributions were consistently dominated by long-chain $\mathrm{C}_{25}-\mathrm{C}_{36}$ homologs that exhibited an odd-carbon number predominance and maxima centered on $n-\mathrm{C}_{29}$ or $n-\mathrm{C}_{31}$. Total $n$-alkanes and UCM ranged from 15.9 to $61.8 \mathrm{ng} / \mathrm{m}^{3}$ and $80.1-398.3 \mathrm{ng} / \mathrm{m}^{3}$, respectively (Table 1). Total $n$-alkanes and UCM concentrations generally displayed lower values in summer, then gradually increased in fall and peaked in the winter time before a sharp decline in spring time. Compared to the $n$-alkane fraction, there was a distinct decline in February for the UCM component (Table 1). Hierarchical cluster analysis of contents of all $n$-alkanes distinguished four groups according to similarity of their molecular content characteristics: short-chain (including $\left.n-\mathrm{C}_{15}-n-\mathrm{C}_{17}\right)$;, long-chain $\left(n-\mathrm{C}_{29}-n-\mathrm{C}_{36}\right)$; mixture-chain $\left(n-\mathrm{C}_{19}\right.$, $n-\mathrm{C}_{20}, n-\mathrm{C}_{27}$ and $\left.n-\mathrm{C}_{28}\right)$; and middle chain $\left(n-\mathrm{C}_{21}-n-\mathrm{C}_{26}\right)$ homologs (Supplementary Figure S2a). Meanwhile, the Carbon Preference Index $\left(\mathrm{CPI}_{\Sigma 15-36}\right)$ values ranged from 1.3 to 2.0 for all $n$-alkanes, 1.3-2.1 for short-chain $\left(\mathrm{C}_{15}-\mathrm{C}_{17}\right)$ homologs, $0.5-0.8$ for middle-chain $\left(\mathrm{C}_{21}-\mathrm{C}_{26}\right)$ homologs, and 2.1-2.8 for long-chain $\left(\mathrm{C}_{29}-\mathrm{C}_{36}\right)$ homologs (Table 1$)$. The Carbon Preference Index (CPI) is a geochemical proxy to evaluate the preference of odd to even carbon number homologs, in this study, a simplified CPI calculation was used as the ratio between the sum of the abundances of prescribed odd-numbered and even-numbered homologs. The CPI was used to identify the distribution of recent biogenic matter and anthropogenic (petroleum) or petrogenic materials, where a CPI equal to approximately one, three and ten indicated the characteristics of petroleum residues, shale sources and degraded tissues of terrestrial plants, respectively [24]. Thus, $n$-alkanes CPI results implied a significant petroleum-derived hydrocarbon input in Xiamen while the middle-chain homologs showed most petroleum-derived signal with extremely low $\mathrm{CPI}_{\Sigma 21-26}$ values (Table 1).

The concentration of short-chain $n$-alkane was very low, and exhibited no obvious temporal patterns with three peaks in August, November-December and spring (March-April) embedded in a pattern of relatively small variations for other times of the year (Figure 3a). Long-chain $n$-alkanes were 10 to 100 times more abundant than short-chain homologs, with the highest values in the early spring time (March) and a second peak in the fall (Figure 3a,b). With the exception of the high values of UCM in April, middle-chain $n$-alkanes and UCM concentrations generally displayed a similar temporal variability, with higher values in cool seasons during November to March and lower values in warm seasons during May to October (Figure 3c). Temporal variability in concentrations of high-molecular-weight mixture-chain $n$-alkanes (i.e., $\mathrm{C}_{27}, \mathrm{C}_{28}$ ) was closer to that of long-chain homologs whereas low-molecular-weight mixture-chain homologs looked more like short-chain homologs (Figure 3d). 

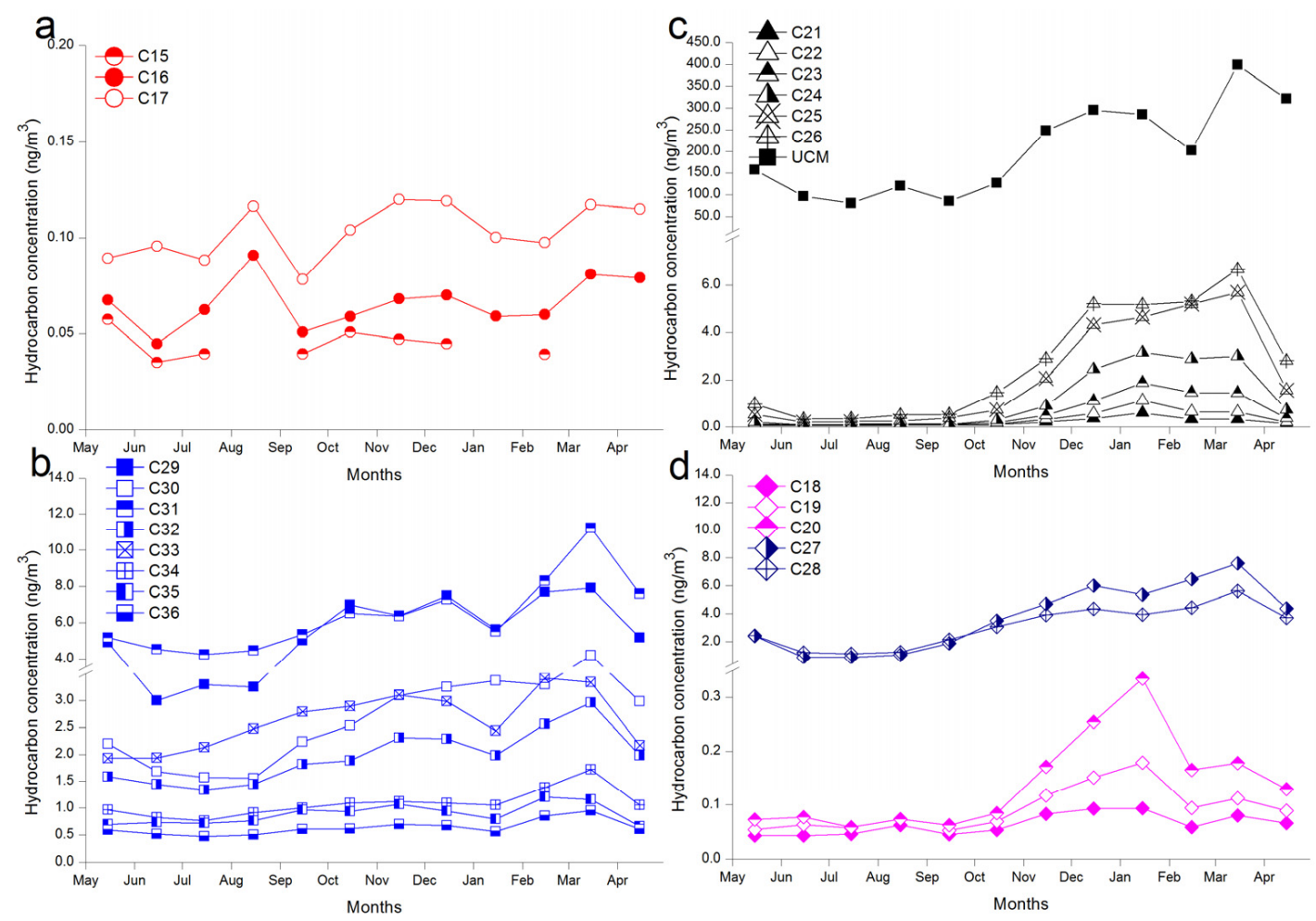

Figure 3. Temporal variations in individual hydrocarbon concentrations of ambient air aerosols in south coastal Xiame. (a) short-chain homologs; (b) long-chain homologs; (c) middle-chain homologs plus unresolved complex matters (UCM); and (d) mixture-chain homolgs.

\subsection{2. $n$-FAs}

Distributions of $n$-FAs from $n-\mathrm{C}_{12}-\mathrm{C}_{32}$ (n-FAs) in all 12 aerosol samples were determined, and exhibited a bimodal pattern with an even-carbon number predominance, a maxima centered on $n-C_{16}$ for shorter chain FAs $\left(n-C_{10}-C_{20}\right)$ and $n-C_{24}$ for longer chain FAs $\left(n-C_{22}-C_{32}\right)$. Unsaturated $n$-FAs were dominated by $n-\mathrm{C}_{18 \text { : homologs }}\left(\mathrm{C}_{18: 1}, \mathrm{C}_{18: 2}, \mathrm{C}_{18: 3}\right)$ and a lesser amount of $n-\mathrm{C}_{16: 1}$ homologs. The concentration of total $n$-FAs ranged from 51.9 to $91.6 \mathrm{ng} / \mathrm{m}^{3}$, with three peaks in August, December and spring time, embedded in a pattern of relatively small variation for other times of the year (Table 1). Based on the Hierarchical cluster analysis of the content of all even-carbon-numbered $n$-FAs, homologs of the $n$-FA fraction were divided into three groups according to the similarity of the temporal variation: (i) short-chain saturated homologs including $n-\mathrm{C}_{12}-n-\mathrm{C}_{20}$ FAs; (ii) short-chain unsaturated homologs including $n-\mathrm{C}_{16:: 1}, n-\mathrm{C}_{18: 1}, n-\mathrm{C}_{18: 2}, n-\mathrm{C}_{18: 3} \mathrm{FAs}$; and (iii) long-chain homologs including $n-\mathrm{C}_{22}-n-\mathrm{C}_{31}$ FAs (Supplementary Figure S2b). Odd-chain $n$-FAs were excluded due to their lower abundance and ambiguous sources. Carbon Preference Index $\left(\mathrm{CPI}_{\Sigma 12-32}\right)$ values ranged from 13.7 to 28.6 for all saturated $n$-FAs, 28.1-50.9 for short-chain $\left(\mathrm{C}_{12}-\mathrm{C}_{21}\right)$ homologs, 3.0 to 4.2 for long-chain $\left(\mathrm{C}_{22}-\mathrm{C}_{32}\right)$ homologs (Table 1), which indicated that short-chain $n$-FAs were originated from biogenic emission whereas long-chain $n$-FAs were likely to derive from crustal OM (e.g., surface soil OC).

The concentration of short-chain homologs showed a pattern of relatively small variations for the entirety of the year, but were slightly higher in August, November-December and spring (March-April) (Figure 4a). Long-chain $n$-FAs were less than one thirtieth of short-chain homologs and exhibited a similar pattern of temporal variability to that of the long-chain $n$-alkanes, with highest values in the early spring time (February-April) and a second peak in the fall (Figure $4 \mathrm{~b}$ ). Unsaturated $n$-FAs exhibited different seasonal patterning depending on the degree of saturation; the monounsaturated $n-C_{18}$ FA was a predominant compound for all unsaturated $n$-FAs with a higher concentration in summer (July-August) and spring (April) (Figure 4c). 

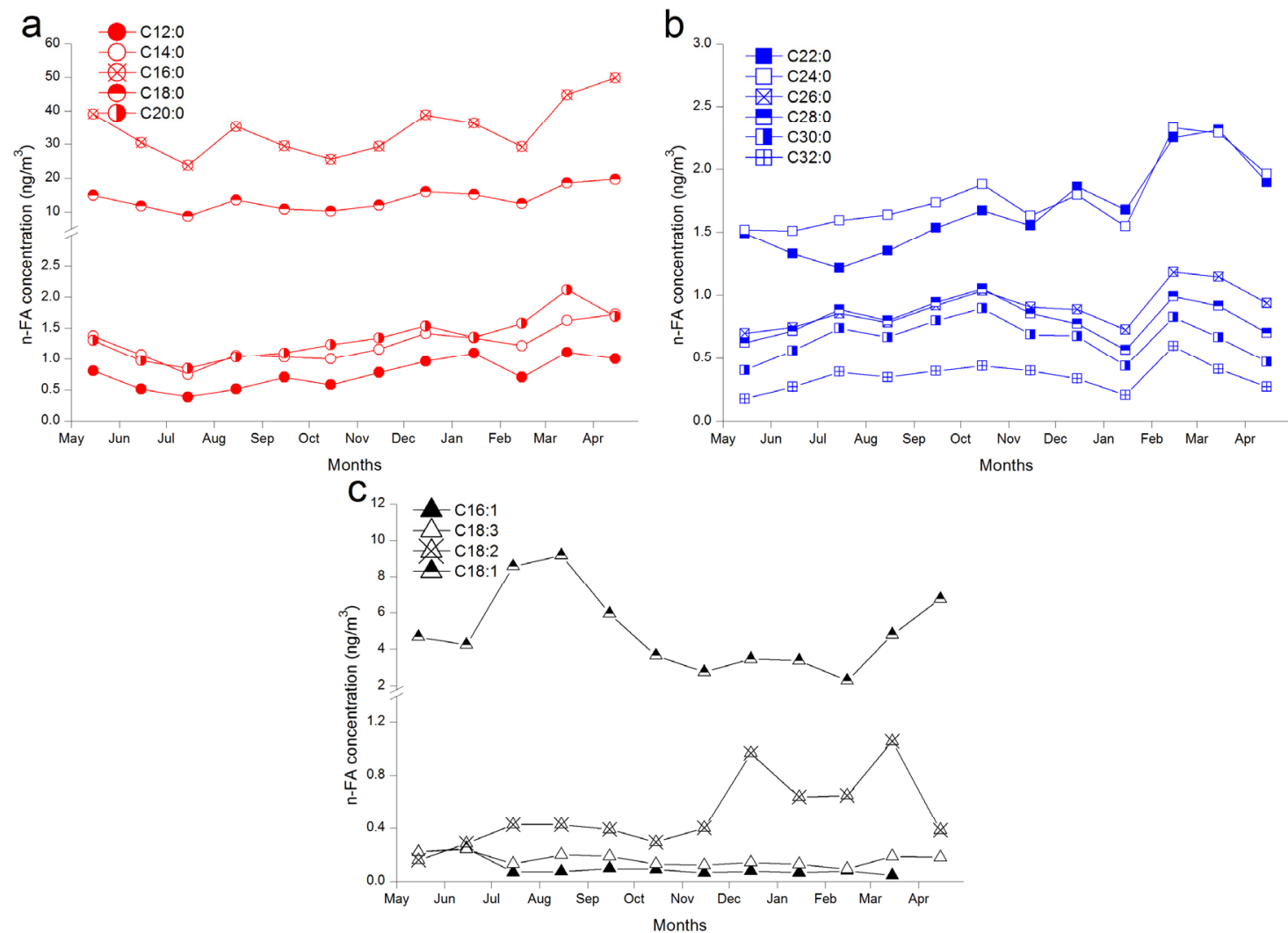

Figure 4. Temporal variations in individual $n$-FA concentrations of ambient air aerosols in south coastal Xiamen. (a) short-chain saturated homologs; (b) long-chain saturated homologs; and (c) unsaturated homologs.

\subsubsection{Alkanols}

The alkanols consisted primarily of $n$-alkanols and a minor amount of sterols. $C_{16}$ to $C_{32} n$-alkanols exhibited an even-carbon number and long-chain predominance, with a maximum centered on $n-C_{28}$ or $n-C_{30}$. The concentration of total alkanols ranged from 11.3 to $35.1 \mathrm{ng} / \mathrm{m}^{3}$, and exhibited a similar pattern of temporal variability to that of the total $n$-alkanes, with lower values in the warm seasons (summer and fall) and higher values in cool seasons (winter and early spring) (Table 1). Based on the Hierarchical Cluster Analysis of even $n$-alkanol, contents revealed three groups: short-chain homologs $\left(\mathrm{C}_{16}, \mathrm{C}_{18}\right.$ and $\mathrm{C}_{20} n$-alkanols), longer-chain homologs ( $\mathrm{C} \geq 22$ alkanols); and sterols (Supplementary Figure S2c). Odd-chain $n$-alkanols were excluded due to lower abundances and ambiguous sources. Carbon Preference Index $\left(\mathrm{CPI}_{\Sigma 22-32}\right)$ values ranged from 8.3 to 15.5 for long-chain $\left(\mathrm{C}_{22}-\mathrm{C}_{32}\right)$ homologs, suggesting long-chain $n$-alkanols were sourced from the biogenic emission (Table 1 ).

The concentration of short-chain $n$-alkanols showed a "S-shape" temporal variation, with the highest values in winter and the lowest values in summer (Figure 5a). Long-chain $n$-alkanols were about 8 times more abundant than short-chain homologs, with the highest values in early spring time (March) and a second peak in fall (Figure 5b). Due to the most abundant sterol homologs, cholesterol was determined with a temporal variability similar to that of short-chain $n$-alkanols (Figure $5 c$ ). 


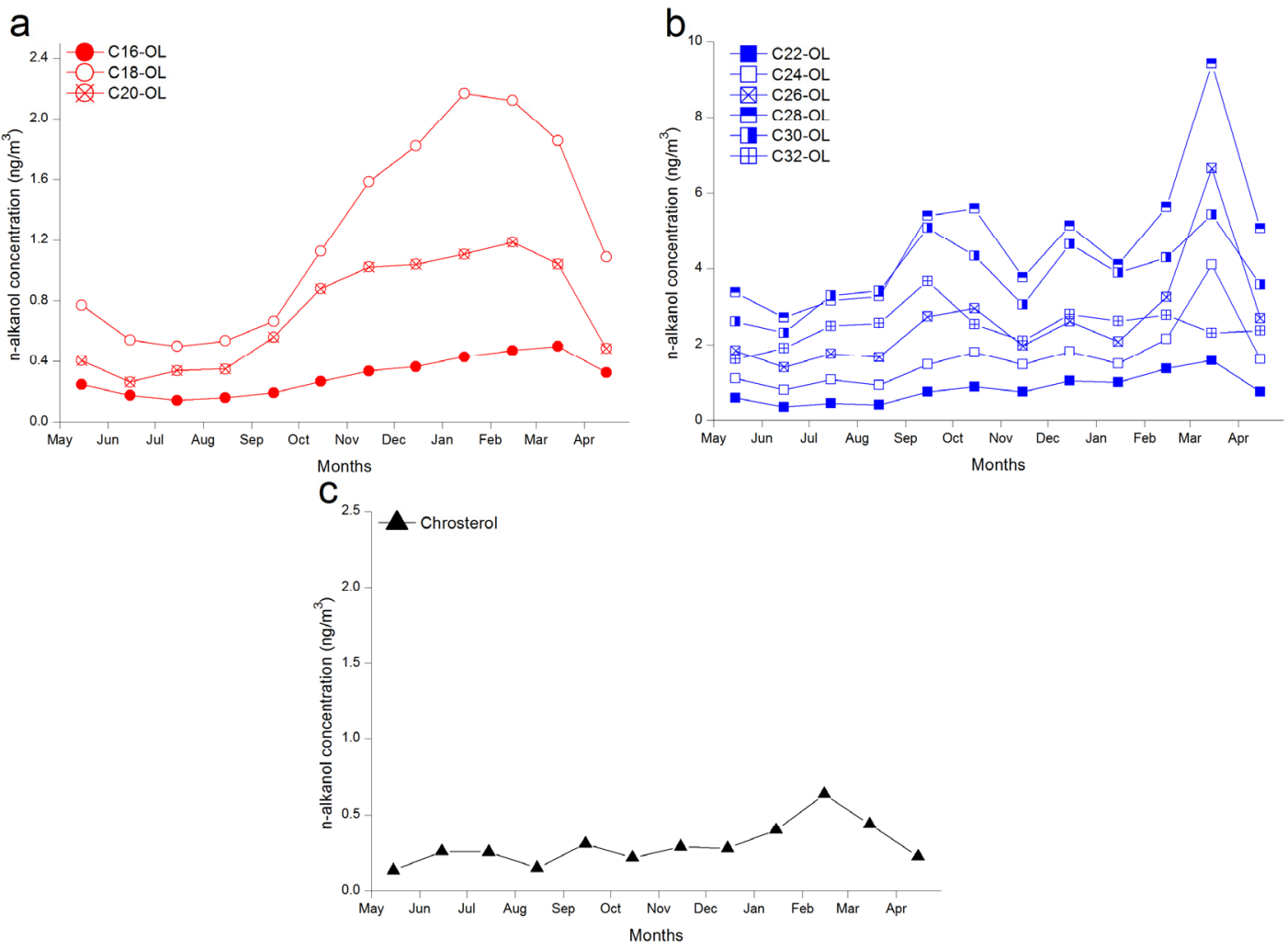

Figure 5. Temporal variations in individual alkanol concentrations of ambient air aerosols in south coastal Xiamen. (a) short-chain n-alkanols; (b) long-chain n-alkanols; and (c) cholesterols.

\section{Discussion}

\subsection{Organic Aerosols Provenance}

\subsubsection{Insight from Bulk Characteristics}

Due to the Super El Nino during 2015-2016, the whole Chinese coastal area had a relatively warm winter with low-frequent and weak cold-air activity [21], which meteorological conditions preventing to the elimination of haze episodes that usually occur in winter months in China. This explains why the TSP of Xiamen in winter and early spring of 2016 (January-April 2016) were much higher than that in spring of 2015 (May). The TOC in the Xiamen OA displayed $\delta^{13} \mathrm{C}$ values $(-25.2 \%$ to $-27.0 \%$; Table 1$)$ that indicated a dominant $\mathrm{C}_{3}$ terrestrial plant signal $\left(\delta^{13} \mathrm{C}=-22 \%\right.$ to $-33 \%$; average $-27 \%$ ) with less other ${ }^{13} \mathrm{C}$ enriched OM source [6]. Probably, two higher $\delta^{13} \mathrm{C}$ periods (Figure 2b) could be explained by distinct ${ }^{13} \mathrm{C}$ enriched $\mathrm{OA}$ contributions. For examples, grassy $\mathrm{C}_{4}$ plant residues $\left(\delta^{13} \mathrm{C}=-9 \%_{0}\right.$ to $-16 \%$; average $-13 \%$ ) [6] or marine $\mathrm{OM}\left(\delta^{13} \mathrm{C}=-22 \%\right.$ to $-19 \%$; average $-20 \%$ [25] via air-sea exchange, as well as heavy carbon isotopic fossil fuel combustion residues, may be responsible for increasing local inputs of ${ }^{13} \mathrm{C}$-enriched TOC (Figure $2 \mathrm{~b}$ ). In order to distinguish and examine temporal variability in contribution from different $\mathrm{OM}$ source, we further examine molecular signals in order to derive insights into the intrinsic temporal variability of OA in Xiamen.

\subsubsection{Insight from Lipid Biomarker Composition}

\section{Plant Wax Lipids}

Long-chain $n$-alkanes $\left(\geq \mathrm{C}_{27}\right)$, n-FAs $\left(\geq \mathrm{C}_{22}\right)$ and $n$-alkanols $\left(\geq \mathrm{C}_{22}\right)$ are generally considered to predominantly derive from vascular plant waxes, which are also regarded as tracers of terrestrial vascular plant OM [26-29]. Figures 3b, 4b and 5b illustrate that more plant wax was detected in the 
cold season (December, February-March). Therefore, higher plant wax lipid concentrations in late fall-winter time are probably caused by the higher wax content in dead leaves and from strong north wind abrasion (Figure 1; December 2015). Alternatively, the formation of the thermal inversion layer in winter and spring inhibits material diffusion, which apparently result in enhanced TSP and TOC yields (Figure 2a) in ambient aerosols as well as plant wax lipid concentrations (Figures 3b, $4 b$ and 5b). As discussed above, both bulk material and source-specific lipid concentrations are significantly influenced by meteorological conditions, which limits the use of biomarker concentrations as proxies for evaluating the relative contribution of various source OA. In order to estimate temporal variation in the terrestrial plant source materials contribution relative to bulk OA materials, we use the ratio between the plant wax lipid concentration and total lipids concentration to cancel out material accumulation due to the thermal inversion layer effect.

Plant wax-derived $n$-alkanes generally have a higher CPI index with a strong odd-numbered predominance (4.3-40.3) [26], while plant wax-derived $n$-FAs and $n$-alkanols also have a higher CPI index with a strong even-numbered predominance. However, $n$-FAs and $n$-alkanols are usually expected to be free of any fossil sources contribution [30,31]. In contrast, long-chain $n$-alkane signatures in environmental samples are frequently influenced by natural (i.e., from source rocks) or anthropogenic fossil hydrocarbons $[24,26,32]$ in addition to modern leaf wax inputs. Since it is known that $n$-alkanes from fossil sources have a CPI of one, the relatively low CPI values of long-chain $n$-alkanes (2.1-2.8) in this study echo previous studies and reflect fossil sources contribution having lower CPI values. Therefore, if long-chain $n$-alkanes are used for a proxy as plant wax input, which should be corrected for fossil source contribution by subtracting the average of the neighboring even carbon numbered homologs which are assumed to be exclusively of fossil (e.g., petroleum-derived) origin, then: Wax $C_{n}=C_{n}-\left[\left(C_{n+1}+C_{n-1}\right)\right]$ (see details from [8]).

The plant wax contribution in the aerosol over Xiamen was $15 \%-34 \%$ of the total $n$-alkanes, $6 \%-13 \%$ of the total $n$-FAs and $80 \%-93 \%$ of the total alkanols (Figure 6 ). The high diversity of plant wax contribution estimation, based on the above three groups of lipids, can be caused by differences in the degree of source heterogeneity and proximity of the terrestrial plant source $[26,33,34]$. For example, short-chain $n$-FAs, especially $\mathrm{C}_{16}$ and $\mathrm{C}_{18}$ homologs, are ubiquitous lipid components and can be derived from in situ autotrophic and heterotrophic microbial activity, as well as from vascular plant input [35-37]. Thus, the proportion of plant wax input of total $n$-FAs must be underestimated significantly (Figure 6). Meanwhile, the relative low plant wax contribution estimated by $n$-alkanes suggests a large contribution from fossil residues into ambient aerosols of Xiamen. However, the higher abundance of plant wax $n$-alkanols in living and decomposing plant tissue relative to long-chain $n$-FAs and $n$-alkanes [38], coupled with their greater activities [39], may thus explain their higher plant wax contribution (Figure 6). Compared to non-terrestrial plant source, the relative contribution of terrestrial plant source is higher in summer and early fall and lower in winter and early spring (Figure 6), coinciding with the seasonal variability in plant growth.

Moreover, seasonal patterns of plant wax lipids not only provide signals of variations in terrestrial plant contribution, but also insight into change of terrestrial plant community. For example, $C_{29}$ and $C_{31}$ homologs are two predominant $n$-alkanes. Previous observations pointed out $C_{29} / C_{31} n$-alkane ratios in shrubs are generally higher than those in grasses [40]. Our molecular distribution results (Figure 7) indicate that $C_{29} / C_{31} n$-alkane ratios showed higher values during fall, winter and sometimes spring (May), but are lowest during summer and early spring, which is in agreement with more woody plant contribution in the former period and more grass contribution in the latter period. In addition, Figure 7 indicates a clear positive correlation between the $C_{29} / C_{31} n$-alkane ratios and wind speeds. This implies a prevalent and strong northerly wind from the land in the fall and winter, which tends to carry more relative coarse woody residues-containing particles which might have generated from the inland/forest of the southern region in China; whereas a prevalent and gentle southerly wind from the ocean in summer time tends to carry more relative fine grass residues-containing particles, which may experience long distance transport from their origins in South Asia. Overall, research on plant wax 
lipids of coastal ambient aerosols provides a better understanding on the biogeochemical process of wind-borne terrestrial $\mathrm{OM}$ from continental environments to marine environments.

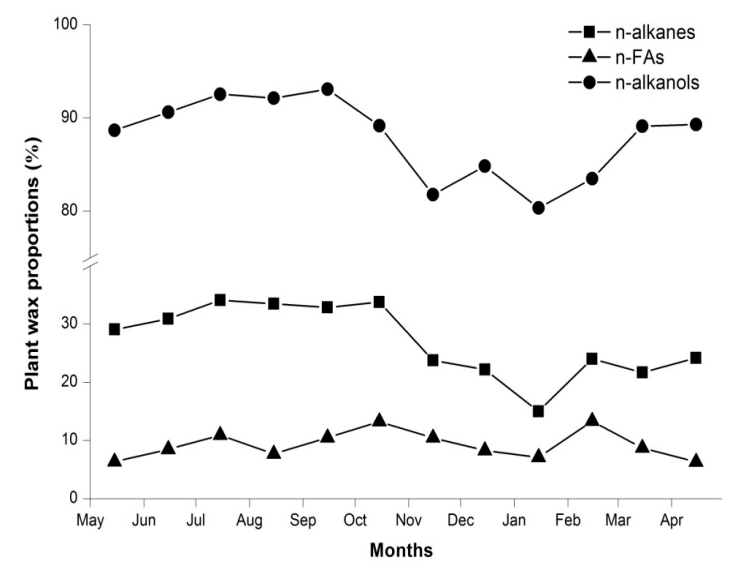

Figure 6. Temporal variations in plant wax contributions (ratios between concentration of plant wax lipids relative to that of total lipids) of different types of lipids ( $n$-alkanes: square; $n$-FAs: triangle; $n$-alkanols: cycle) in south coastal Xiamen. Wax in $n$-FAs and $n$-alkanols is the sum of $\geq \mathrm{C}_{22}$ homologs. Wax in $n$-alkanes is the sum of $\geq \mathrm{C}_{27}$ homologs corrected for fossil source contribution.

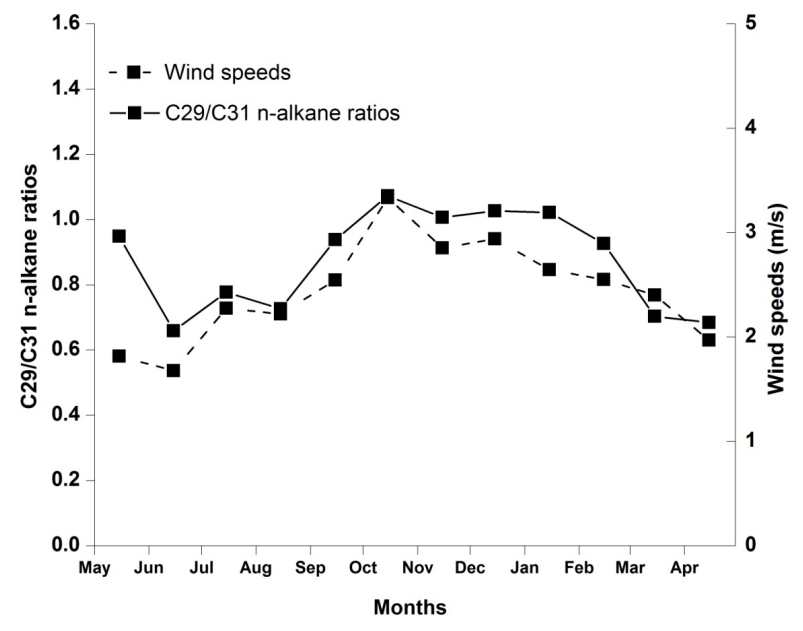

Figure 7. Temporal variations in $\mathrm{C}_{29} / \mathrm{C}_{31} n$-alkane ratios of air ambient aerosols (the solid line) and monthly average wind speeds (the dash line) in south coastal Xiamen.

\section{Anthropogenic Activities and Fossil Fuel Lipids}

In all 12 aerosol samples, hydrocarbon compounds exhibited a series of resolved alkanes (R) with an envelope of unresolved complex homologs (UCM). UCM is often interpreted to be derived from engine emissions, lubricants and fuels [8]. An abundant UCM in these hydrocarbon fractions is characteristic of weathered petroleum or fossil carbon, which indicates that $\mathrm{OA}$ in Xiamen receive hydrocarbon input from anthropogenic petroleum sources. Therefore, middle-chain $\left(C_{21}-C_{26}\right)$ $n$-alkanes have been found to mainly originate from fossil fuel sources with low $\mathrm{CPI}_{\Sigma 21-26}(0.5-0.8$; Table 1), which also coincides with the temporal variability of UCM homologs. Higher concentrations in winter and spring (November-March) suggest that there are more petroleum-derived OM due to meteorological conditions (thermal inversion layer), and corresponded to peaks of other pollutant proxies such as $\mathrm{SO}_{2}, \mathrm{CO}$ and $\mathrm{NO}_{2}$ [41]. Furthermore, the $\mathrm{UCM} / \mathrm{R}$ ratio is often utilized to assess the magnitude of petroleum contributions to ambient aerosols, where a UCM/R ratio $>4$ reflects severe contamination by petroleum products [42]. Our observations reflect the relatively heavy anthropogenic 
activities and fossil fuel pollution in the south coastal area of Xiamen due to a busy shipping/urban traffic with industrial development and urban construction. With exception of February, the UCM/R ratio is relatively high during the winter and spring of Xiamen (5.6-8.5; Table 1). Lower contributions of petroleum-derived OM (UCM:R = 3.4) in February can be explained by a "holiday effect" when anthropogenic activities have been proved to be sharply reduced and other pollutant proxies also show a low level [43].

\section{Marine and Microbial Lipids}

Short-chain homologs $\leq \mathrm{C}_{20}$ are usually considered as marine or microbial biomarkers, since they do not dominate in terrestrial plant wax but are highly abundant in the aquatic biomass, soil microbia or bacteria $[35,37,44-46]$. For short-chain unsaturated $n$-FAs (Figure 4c), July-September showed the highest yields, which is consistent with more marine material contribution due to enhanced air-sea exchange via the frequent typhoon events originating from the Pacific Ocean and more airborne microbial activities in warm and wet seasons (Supplementary Figure S1a,c). Meanwhile, March-April exhibits a second peak, which could be attributed to more microbial or bacterial activities in the rainy season, which is in agreement with relatively high humidity and warming (Supplementary Figure $\mathrm{S} 1 \mathrm{a}-\mathrm{c})$. In contrast, short-chain $n$-alkanols showed higher yields in late fall and winter time (Figure $5 \mathrm{~b}$ ), suggesting a predominant terrestrial microbial lipids contribution derived from soil abrasion by a strong northerly wind. However, Short-chain $n$-alkanes and saturated $n$-FAs exhibited a relatively invariant temporal variation during the whole research period (Figures 3a and 4a). Although the two short-chain compounds are highly abundant in marine and microbial materials, short-chain $n$-alkanes are frequently contaminated by crude petroleum residues containing $n$-alkanes ranging from $C_{15}$ to $\mathrm{C}_{35}$ [33] while saturated short-chain $n$-FAs may be influenced by terrestrial plant wax containing saturated $n$-FA ranging from $\mathrm{C}_{14}$ to $\mathrm{C}_{30}$ [34]. Additional sources of short-chain $n$-alkanes and saturated $n$-FAs may conceal the temporal change of marine and microbial-derived lipids. Overall, unsaturated $n$-FAs and short-chain $n$-alkanols seems like to be better tracers for marine/microbial sources and terrestrial microbial sources, respectively.

Microbial lipids are important chemical constituents in the cell membrane of microorganism. Therefore, unsaturated FAs are unstable and rapidly transform into saturated FAs, so unsaturated FAs is often more abundant in microorganisms and their fresh metabolites. As discussed above, the temporal variability in concentration of total unsaturated FAs (the sum of $n-C_{16: 1}, n-C_{18: 1}, n-C_{18: 2}$, and $n$ - $\left.\mathrm{C}_{18: 3}\right)$ implies a more short-residence-time microbial OM contribution in the transition time between summer and fall (July-September) with a second peak in April during spring time (Table 1), which are also consistent with the seasonal variability in airborne bacterial growth and characteristics of the distribution of epidemic season over Xiamen [47]. Compared to monounsaturated homologs, polyunsaturated $n$-FAs are found only as trace constituents (Figure 4c). Overall, the microbial community of aerosols, including airborne bacteria and viruses, is an important component in ambient aerosols, part of which can potentially cause public health problems. It can be seen from study on the microbial lipids in ambient aerosols can reflect airborne microbial abundance and activity to a certain degree.

Moreover, our study has showed that saturation of $n$-C $\mathrm{C}_{18}$ FAs $\left(\Omega_{18}\right)$ significantly co-vary with air temperature, with a distribution of more polyunsaturated homologs in the cold seasons (Figure 8). It implies that lipid biosynthesis of airborne microorganism is strongly controlled by temperature, and unsaturated FAs may enhance the ability of organisms to survive in a cold climate by keeping cell membranes stable and flexible due to more double bounds [48]. Moreover, the $n-C_{18: 1} / n-C_{18: 0}$ ratio has been widely used as an indication of recent biogenesis [5,7]. The higher the $n-C_{18: 1} / n-C_{18: 0}$ ratio in the coastal aerosols over Xiamen from July to September (0.57-1.01; Table 1) suggests that there were more fresh aerosols and/or less degradation of the FA, which can be attributed to marine microbial sources (e.g., microalgae, bacteria) in the upper layer via bubble bursting processes or enhanced airborne microbial source under the warm and wet atmospheric conditions characterized by a prevalent sea 
wind during this period (Supplementary Figure S1a,c and Figure 1 ). The lower $n-C_{18: 1} / n-C_{18: 0}$ ratio in winter (0.22-0.25; Table 1) suggests that the aerosols in air are aged and compared well to a long-distance sample with a relatively long degradation time (0.35 [7]; 0.38 [49]).

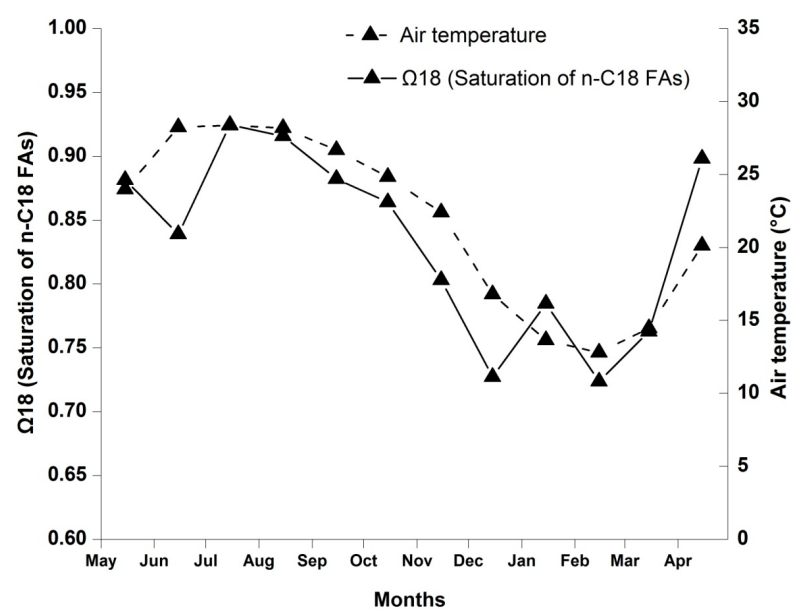

Figure 8. Temporal variations in the saturation of $n-C_{18}$ FA homologs $\left(\Omega_{18}\right)$ of ambient air aerosols (the solid line) and the monthly average air temperature (the dashed line) in south coastal Xiamen. $\Omega_{18}=\left[C_{18: 1}-C_{18: 3}\right] /\left[C_{18: 1}+C_{18: 2}+C_{18: 3}\right]$.

\subsection{Temporal Variability on Different Sources of Organic Aerosols}

The bulk and source-specific lipid biomarker concentrations described above reveals an integrated picture of OA in Xiamen where the temporal variability on various OA is influenced by both meteorological conditions and the OA sources intensity to different degree. In order to better understand the effect of seasonal change on the supply of various OA sources, the TOC normalized contents of various source-specific lipids were also used to remove the influence of boundary layer dynamics which usually have a strong effect on OA in winter (see above discussion; Figures 3-5). After corrections for the boundary layer effect, marine/microbial lipids showed high proportions relative to the TOC in summer and autumn but low proportions in winter (Figures 9a and 10c), implying marine OA input in warm seasons is much stronger than that in cold seasons. Short-chain $n$-alkanols, terrestrial microbial lipid biomarkers, exhibit a peak in late autumn-early winter (Figure 11a), which coincides with previous assumption of an enhanced terrestrial microbial source input in the background of a strongly northerly wind during this period in Xiamen. Meanwhile, the temporal variability in the TOC normalized contents of plant wax lipids (Figures $9 b, 10 b$ and $11 b$ ) indicates a stronger terrestrial biogenic OA source in warm and wet seasons (summer/autumn) in this coastal region. In contrast, the TOC normalized contents and mass concentrations of fossil fuel lipids showed a similar seasonal pattern with high proportions during winter and early spring time (Figures $3 c$ and $9 c$ ), indicating that source intensity and the thermal inversion layer plays a synergistic effect on fossil-derived OA pollution in cold seasons. As previously discussed, the "holiday effect" results in weakening the intensity of petroleum-derived OA source. 

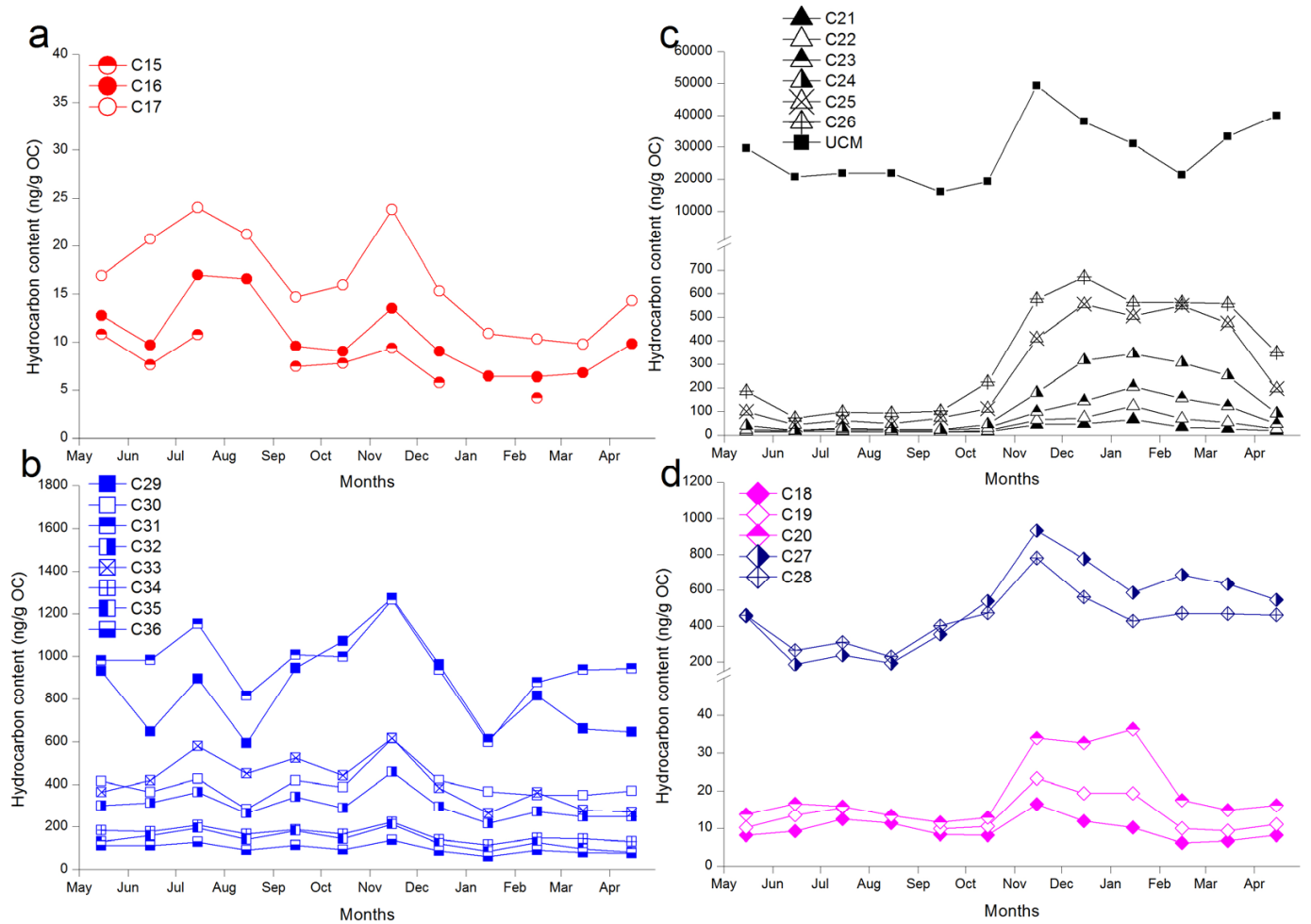

Figure 9. Temporal variations in individual hydrocarbon TOC normalized contents of ambient air aerosols in south coastal Xiamen. (a) short-chain homologs; (b) long-chain homologs; (c) middle-chain homologs plus UCM; and (d) Mixture-chain homologs.
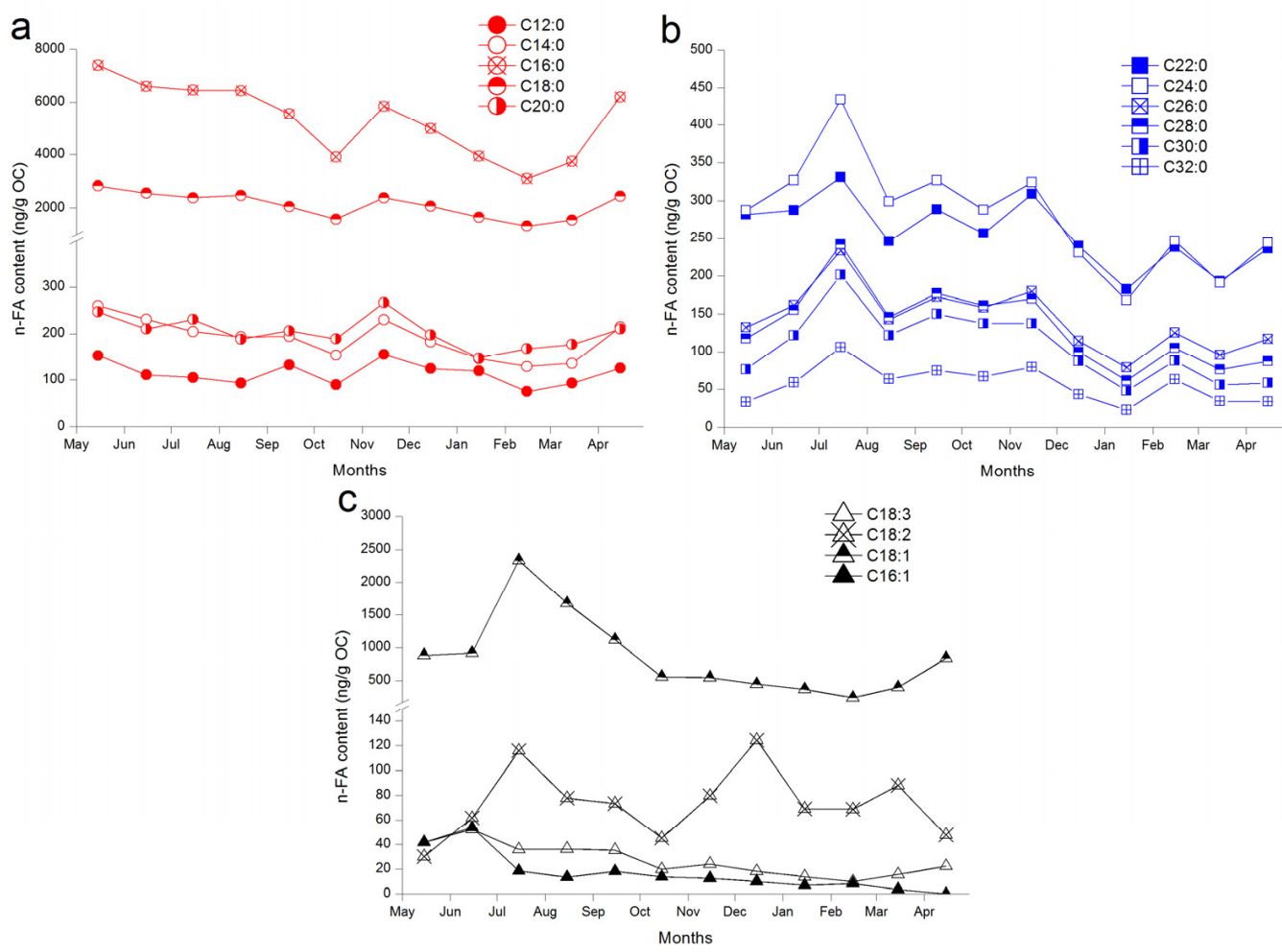

Figure 10. Temporal variations in individual $n$-FA TOC normalized contents of ambient air aerosols in south coastal Xiamen. (a) short-chain saturated homologs; (b) long-chain saturated homologs; and (c) unsaturated homologs. 
a
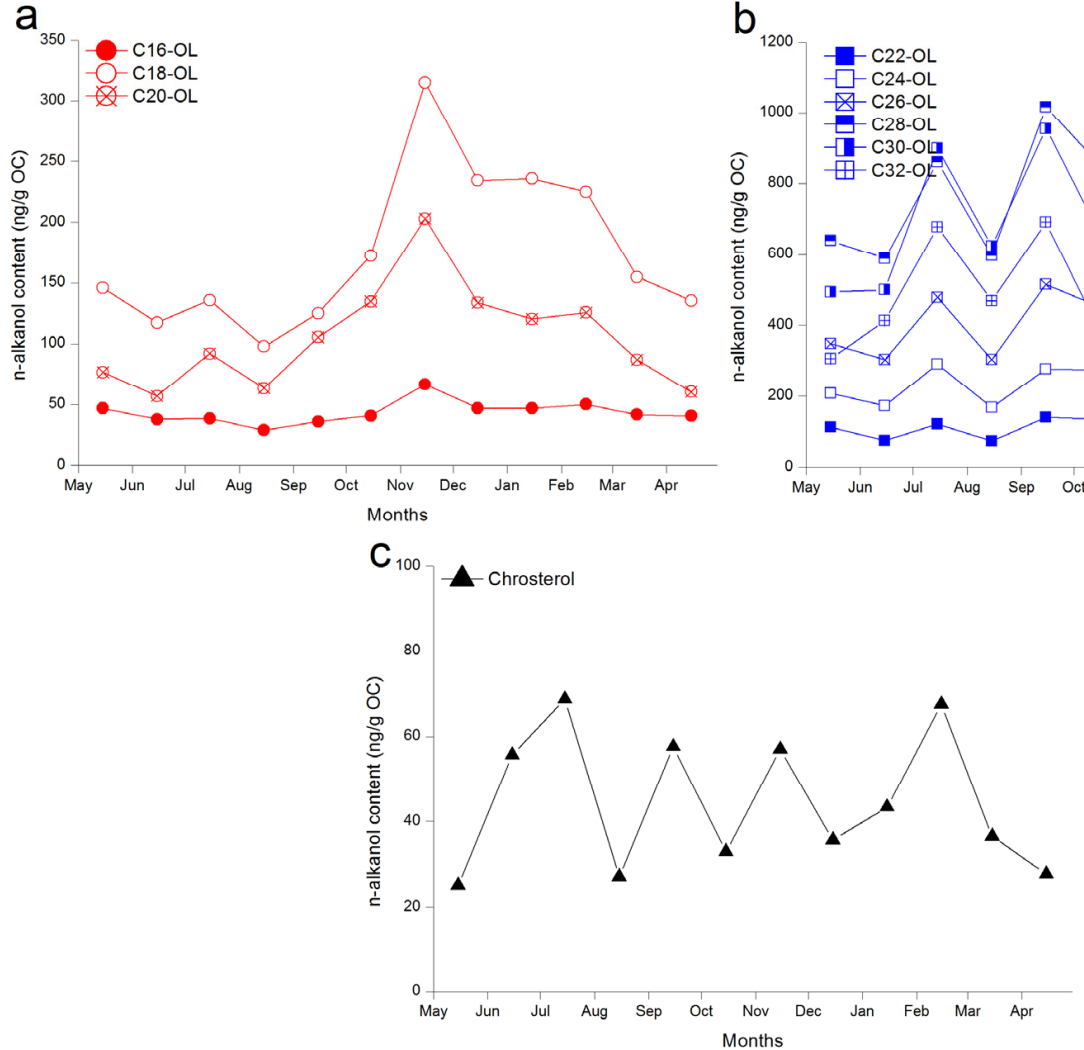

$b_{1000}$

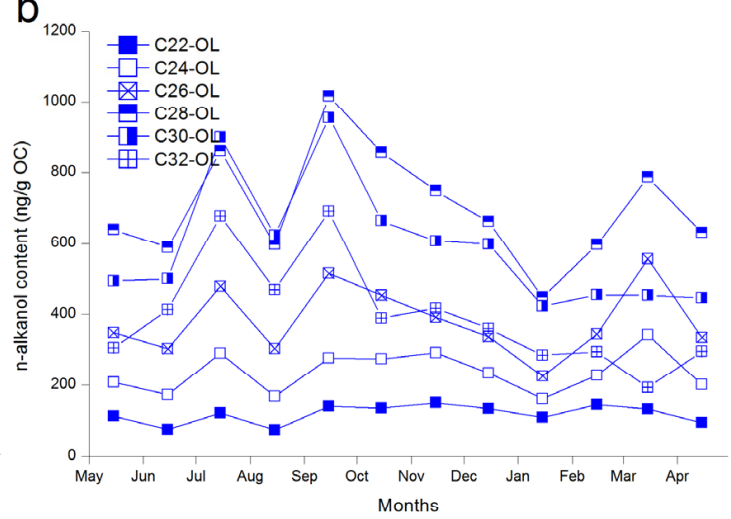

Figure 11. Temporal variations in individual alkanol TOC normalized contents of ambient air aerosols in south coastal Xiamen. (a) short-chain $n$-alkanols; (b) long-chain $n$-alkanols; and (c) cholesterols.

\subsection{Comparison of Organic Aerosol with other Major Coastal Cities}

In order to further understand the spatial distribution of various airborne OM and organic pollutants in ambient aerosols, the results of biogenic and fossil lipids obtained in this study were compared to data gathered from other five coastal cities-Qingdao, China [7]; Hong Kong, China [49]; the southeastern coast of Australia [14]; Rio de Janeiro, Brazil [50]; and Los Angeles, United States of America [5]. Table 2 summarizes the concentrations of hydrocarbons, $n$-FAs and $n$-alkanols, and $\mathrm{UCM} / \mathrm{R}$ ratios for these coastal cities. Compared to inland cities, marine aerosols unavoidably mix with terrigenous aerosols under the major global wind systems. Hydrocarbon data in ambient aerosols indicates that fossil fuel pollution derived from traffic and industrial activities should be a global issue, but cities in the northern hemisphere show heavier pollution with relatively high UCM concentration and UCM/R ratio. Since plant wax FAs only account for $\sim 10 \%$ of the total (Figure 6 ), $n$-FAs are more likely to reflect a dominated marine and microbial signal, which is characterized by a relatively short residence time. $n$-FA concentrations in Table 2 show that fresh marine/microbial biogenic OM exhibits a low contribution in the ambient aerosols of the south coast of China and southeastern coast of Australia, implying more aged biogenic component input with the long-distance transport of marine $\mathrm{OM}$ to the continent. With regard to the total $n$-alkanol, this most likely reflects a terrestrial plant wax signal which show an extremely high plant wax proportion ( $>80 \%$ in total; Figure 6$)$. Ambient aerosols of south coastal cities of China (Xiamen and Hong Kong) show a lower level of terrestrial biogenic OM contribution than that of Australia and the United States. This may be related to the regional wind system (prevalent land or sea wind) and city greening. 
Table 2. Comparison of three lipids data among different coastal cities.

\begin{tabular}{|c|c|c|c|c|c|c|}
\hline \multirow[b]{2}{*}{ Cities } & \multirow[b]{2}{*}{ The Adjacent Sea } & \multicolumn{3}{|c|}{ Hydrocarbons } & \multirow{2}{*}{$\begin{array}{c}n \text {-FAs } \\
\text { Concentrations }\end{array}$} & \multirow{2}{*}{$\begin{array}{c}\text { n-Alkanols } \\
\text { Concentrations }\end{array}$} \\
\hline & & $\begin{array}{c}n \text {-Alkanes } \\
\text { Concentrations }\end{array}$ & $\begin{array}{c}\text { UCM } \\
\text { Concentration }\end{array}$ & $\mathrm{U} / \mathrm{R}$ & & \\
\hline Xiamen & East China Sea & $\begin{array}{l}\text { ave. 33.9; } \\
15.9 \sim 61.8\end{array}$ & $\begin{array}{l}\text { ave. 201.2; } \\
80.1 \sim 398.3\end{array}$ & $\begin{array}{l}\text { ave. 5.3; } \\
3.2 \sim 8.5\end{array}$ & $\begin{array}{l}\text { ave. } 66.8 ; \\
51.9 \sim 91.6\end{array}$ & $\begin{array}{l}\text { ave. } 20.0 ; \\
11.3 \sim 35.1\end{array}$ \\
\hline Qingdao & Yellow Sea & $\begin{array}{l}\text { ave. 217.1; } \\
52.8 \sim 371.4\end{array}$ & & & $\begin{array}{l}\text { ave. 653.6; } \\
247.3 \sim 925.2\end{array}$ & \\
\hline Hongkong & South China Sea & 235.5 & & & 208.7 & 40.5 \\
\hline $\begin{array}{l}\text { SE coast of } \\
\text { Australia }\end{array}$ & South Pacific Ocean & & $\begin{array}{l}\text { ave. } 43.6 \text {; } \\
1.6 \sim 80^{*}\end{array}$ & $\begin{array}{l}\text { ave. 2.7; } \\
1.1 \sim 5.3\end{array}$ & $\begin{array}{l}\text { ave. 37.3; } \\
\text { 2.8 110 }\end{array}$ & $\begin{array}{l}\text { ave. } 97.2 ; \\
1.7 \sim 380\end{array}$ \\
\hline $\begin{array}{c}\text { Rio de Janeiro, } \\
\text { Brazil }\end{array}$ & Atlantic Ocean & & $\begin{array}{l}\text { ave. } 243.4 ; \\
58.3 \sim 581.2\end{array}$ & $\begin{array}{l}\text { ave. } 3.2 ; \\
1.9 \sim 4.6\end{array}$ & & \\
\hline $\begin{array}{c}\text { Urban } \\
\text { Los Angeles }\end{array}$ & $\begin{array}{l}\text { East of North } \\
\text { Pacific Ocean }\end{array}$ & & 294.1 * & $\begin{array}{l}\text { ave. } 4.6 ; \\
0.6 \sim 13.0\end{array}$ & 379.3 & 1045.3 \\
\hline
\end{tabular}

\section{Conclusions}

The temporal variability of solvent extractable lipid concentrations and ratios in ambient aerosols over Xiamen was investigated over a one-year period (May 2015-April 2016), and findings were discussed in the context of possible sources, transport mechanisms and biogeochemical implications:

Source-specific lipid concentrations vary significantly seasonally in concert with seasonal variabilities of organic source and meteorological conditions, whereas the TOC characteristics co-variation with TSP, imply that the formation of the thermal inversion layer enhances airborne particles, as well as OA, especially in winter and early spring. Nevertheless, characteristics of source-specific lipids reveals that OA over the coastal city is inherently heterogeneous, with at least three distinct components that exhibit distinct and systematic temporal evolutions in proportional abundance and composition: (i) fresh high plant or surface detrital terrestrial plant $\mathrm{OM}$, influenced by the seasonal variability of plant growth and regional wind system; (ii) marine and microbial sources (short turn-over time in ambient aerosols), influenced by sea wind transportation and temperature change; and (iii) fossil OM (derived from shipping traffic, vehicle emission and other fossil fuels combustion), influenced by anthropogenic processes and metrological conditions.

The signatures of source-specific lipids can provide a deep insight into the sources of ambient OA. Base on a series of source-specific lipid homologs, we monitored marine, microbial, terrestrial biogenic $\mathrm{OM}$ and fossil fuel organic pollution simultaneously. Variations in the relative contributions of the three different airborne organic components have significant regional scale carbon cycle implications given their differing connectivity to atmospheric reservoirs and fates. Both natural conditions and human activities exert dominant control on yields and relative contributions of all three organic components in ambient aerosols. The consistent relationships between different sources organic composition and seasonally varying meteorological dynamics found during this time-series investigation provide a means in which to predict past and future changes in the flux and nature of airborne OM fluxes from the south Chinese margin to the adjacent marginal sea. Although source-specific lipid biomarkers can provide us with systematic and detailed information on OA sources, their carbon isotopic compositions could be further studied, such as their occurrence in fluvial or marine particle studies [51,52], to better constrain various $\mathrm{OA}$ source contribution quantitatively.

Supplementary Materials: The following are available online at www.mdpi.com/2073-4433/8/2/33/s1.

Acknowledgments: We thank two anonymous reviewers for their constructive and detailed suggestions, which have greatly improved this paper. We would like to thank Wei Li for sampling help; Haoran Guo for TOC and stable carbon isotope measurements. This work was supported by the National Natural Science Foundation of China (Grant No. 41506089, 41305133). 
Author Contributions: The work presented here was carried out in collaboration with all authors. Shuqin Tao and Liqi Chen conceived and designed the experiments; Xijie Yin and Liping Jiao performed the experiments; Shuqin Tao analyzed the data; Shuhui Zhao is in charge of aerosol sample collection; Shuqin Tao, Liqi Chen and Shuhui Zhao wrote the paper. All authors have read and approved the final manuscript.

Conflicts of Interest: The authors declare no conflict of interest.

\section{References}

1. Wendy Hsiao, W.L.; Mo, Z.-Y.; Fang, M.; Shi, X.-M.; Wang, F. Cytotoxicity of PM $_{2.5}$ and PM $_{2.5-10}$ ambient air pollutants assessed by the MTT and the comet assays. Mutat. Res. 2000, 471, 45-55. [CrossRef]

2. Huang, R.-J.; Zhang, Y.; Bozzetti, C.; Ho, K.-F.; Cao, J.-J.; Han, Y.; Daellenbach, K.R.; Slowik, J.G.; Platt, S.M.; Canonaco, F.; et al. High secondary aerosol contribution to particulate pollution during haze events in China. Nature 2014, 514, 218-222. [CrossRef] [PubMed]

3. Zhang, Z.; Friedlander, S.K. A comparative study of chemical databases for fine particle Chinese aerosols. Environ. Sci. Technol. 2000, 34, 4687-4694. [CrossRef]

4. Jimenez, J.L.; Canagaratna, M.R.; Donahue, N.M.; Prevot, A.S.H.; Zhang, Q.; Kroll, J.H.; DeCarlo, P.F.; Allan, J.D.; Coe, H.; Ng, N.L.; et al. Evolution of organic aerosols in the atmosphere. Science 2009, 326, 1525-1529. [CrossRef] [PubMed]

5. Simoneit, B.R.T.; Mazurek, M.A. Organic matter of the troposphere-II. Natural background of biogenic lipid matter in aerosols over the rural western United States. Atmos. Environ. 1982, 16, 2139-2159. [CrossRef]

6. Guo, Z.; Li, J.; Feng, J.; Fang, M.; Yang, Z. Compound-specific carbon isotope compositions of individual long-chain $n$-alkanes in severe Asian dust episodes in the north China coast in 2002. Chin. Sci. Bull. 2006, 51, 2133-2140. [CrossRef]

7. Guo, Z.; Sheng, L.; Feng, J.; Fang, M. Seasonal variation of solvent extractable organic compounds in the aerosols in Qingdao, China. Atmos. Environ. 2003, 37, 1825-1834. [CrossRef]

8. Simoneit, B.R.; Sheng, G.; Chen, X.; Fu, J.; Zhang, J.; Xu, Y. Molecular marker study of extractable organic matter in aerosols from urban areas of China. Atmos. Environ. 1991, 25, 2111-2129. [CrossRef]

9. Fu, P.Q.; Kawamura, K.; Chen, J.; Charrière, B.; Sempéré, R. Organic molecular composition of marine aerosols over the arctic ocean in summer: Contributions of primary emission and secondary aerosol formation. Biogeosciences 2013, 10, 653-667. [CrossRef]

10. Fu, P.Q.; Kawamura, K.; Pavuluri, C.M.; Swaminathan, T. Molecular characterization of urban organic aerosol in tropical India: Contributions of biomass/biofuel burning, plastic burning, and fossil fuel combustion. Atmos. Chem. Phys. 2009, 7, 129-137. [CrossRef]

11. Schmittkopplin, P.; Ligerbelair, G.; Koch, B.P.; Flerus, R. Dissolved organic matter in sea spray: A transfer study from marine surface water to aerosols. Biogeosciences 2011, 9, 1571-1582. [CrossRef]

12. Lee, J.S.; Weon, B.M.; Park, S.J.; Je, J.H.; Fezzaa, K.; Lee, W.K. Size limits the formation of liquid jets during bubble bursting. Nat. Commun. 2011, 2, 2555-2559. [CrossRef] [PubMed]

13. Eglinton, T.I.; Eglinton, G.; Dupont, L.; Sholkovitz, E.R.; Montluçon, D.; Reddy, C.M. Composition, age, and provenance of organic matter in NW African dust over the Atlantic Ocean. Geochem. Geophys. Geosyst. 2002, 3, 1-27. [CrossRef]

14. Simoneit, B.R.T.; Crisp, P.T.; Mazurek, M.A.; Standley, L.J. Composition of extractable organic matter of aerosols from the Blue Mountains and southeast coast of Australia. Environ. Int. 1991, 17, 405-419. [CrossRef]

15. Lim, H.-J.; Turpin, B.J. Origins of primary and secondary organic aerosol in Atlanta: Results of time-resolved measurements during the Atlanta supersite experiment. Environ. Sci. Technol. 2002, 36, 4489-4496. [CrossRef] [PubMed]

16. Samara, C.; Voutsa, D.; Kouras, A.; Eleftheriadis, K.; Maggos, T.; Saraga, D.; Petrakakis, M. Organic and elemental carbon associated to $\mathrm{PM}_{10}$ and $\mathrm{PM}_{2.5}$ at urban sites of northern Greece. Environ. Sci. Pollut. Res. 2014, 21, 1769-1785. [CrossRef] [PubMed]

17. Zhang, F.; Zhao, J.; Chen, J.; Xu, Y.; Xu, L. Pollution characteristics of organic and elemental carbon in $\mathrm{PM}_{2.5}$ in Xiamen, China. J. Environ. Sci. 2011, 23, 1342-1349. [CrossRef]

18. Bernardoni, V.; Calzolai, G.; Chiari, M.; Fedi, M.; Lucarelli, F.; Nava, S.; Piazzalunga, A.; Riccobono, F.; Taccetti, F.; Valli, G.; et al. Radiocarbon analysis on organic and elemental carbon in aerosol samples and source apportionment at an urban site in northern Italy. J. Aerosol. Sci. 2013, 56, 88-99. [CrossRef] 
19. Matsumoto, K.; Kawamura, K.; Uchida, M.; Shibata, Y.; Yoneda, M. Compound specific radiocarbon and $\delta^{13} \mathrm{C}$ measurements of fatty acids in a continental aerosol sample. Geophys. Res. Lett. 2001, 28, 4587-4590. [CrossRef]

20. Schlag, P.; Kiendlerscharr, A.; Blom, M.J.; Canonaco, F.; Sebastiaan Henzing, J.; Moerman, M.; Prévôt, A.S.H.; Holzinger, R. Aerosol source apportionment from 1-year measurements at the CESAR tower in Cabauw, the Netherlands. Atmos. Chem. Phys. 2016, 16, 8831-8847. [CrossRef]

21. China Environmental State Bulletin in 2015. Available online: http://www.zhb.gov.cn/gkml/hbb/qt/ 201606/t20160602_353078.htm (accessed on 11 January 2017).

22. Fan, X.; Sun, Z. Analysis on features of haze weather in Xiamen city during 1953-2008. Trans. Atmos. Sci 2009, 604-609. (In Chinese)

23. Komada, T.; Anderson, M.R.; Dorfmeier, C.L. Carbonate removal from coastal sediments for the determination of organic carbon and its isotopic signatures, $\delta^{13} \mathrm{C}$ and $\delta^{14} \mathrm{C}$ : Comparison of fumigation and direct acidification by hydrochloric acid. Limnol. Oceanogr. 2008, 6, 254-262. [CrossRef]

24. Pearson, A.; Eglinton, T.I. The origin of $n$-alkanes in Santa Monica basin surface sediment: A model based on compound-specific $\delta^{14} \mathrm{C}$ and $\delta^{13} \mathrm{C}$ data. Org. Geochem. 2000, 31, 1103-1116. [CrossRef]

25. Hedges, J.I.; Keil, R.G.; Benner, R. What happens to terrestrial organic matter in the ocean? Org. Geochem. 1997, 27, 195-212. [CrossRef]

26. Collister, J.W.; Rieley, G.; Stern, B.; Eglinton, G.; Fry, B. Compound-specific $\delta^{13} \mathrm{C}$ analyses of leaf lipids from plants with differing carbon dioxide metabolisms. Org. Geochem. 1994, 21, 619-627. [CrossRef]

27. Eglinton, G.; Hamilton, R.J. Leaf epicuticular waxes. Science 1967, 156, 1322-1335. [CrossRef] [PubMed]

28. Rommerskirchen, F.; Eglinton, G.; Dupont, L.; Rullkötter, J. Glacial/interglacial changes in Southern Africa: Compound-specific $\delta^{13} \mathrm{C}$ land plant biomarker and pollen records from southeast Atlantic continental margin sediments. Geochem. Geophys. Geosyst. 2006, 7, Q08010. [CrossRef]

29. Freeman, K.H.; Colarusso, L.A. Molecular and isotopic records of $\mathrm{C}_{4}$ grassland expansion in the late Miocene. Geochim. Cosmochim. Acta 2001, 65, 1439-1454. [CrossRef]

30. Drenzek, N.J.; Montluçon, D.B.; Yunker, M.B.; Macdonald, R.W.; Eglinton, T.I. Constraints on the origin of sedimentary organic carbon in the Beaufort sea from coupled molecular ${ }^{13} \mathrm{C}$ and ${ }^{14} \mathrm{C}$ measurements. Mar. Chem. 2007, 103, 146-162. [CrossRef]

31. Kusch, S.; Rethemeyer, J.; Schefuß, E.; Mollenhauer, G. Controls on the age of vascular plant biomarkers in black sea sediments. Geochim. Cosmochim. Acta 2010, 74, 7031-7047. [CrossRef]

32. Lichtfouse, É.; Eglinton, T.I. ${ }^{13} \mathrm{C}$ and ${ }^{14} \mathrm{C}$ evidence of pollution of a soil by fossil fuel and reconstruction of the composition of the pollutant. Org. Geochem. 1995, 23, 969-973. [CrossRef]

33. Collister, J.W.; Lichtfouse, E.; Hieshima, G.; Hayes, J.M. Partial resolution of sources of $n$-alkanes in the saline portion of the Parachute Creek Member, Green River Formation (Piceance Creek Basin, Colorado). Org. Geochem. 1994, 21, 645-659. [CrossRef]

34. Wiesenberg, G.L.B.; Schwarzbauer, J.; Schmidt, M.W.I.; Schwark, L. Source and turnover of organic matter in agricultural soils derived from $n$-alkane/ $n$-carboxylic acid compositions and C-isotope signatures. Org. Geochem. 2004, 35, 1371-1393. [CrossRef]

35. Schouten, S.; Klein Breteler, W.C.M.; Blokker, P.; Schogt, N.; Rijpstra, W.I.C.; Grice, K.; Baas, M.; Sinninghe Damsté, J.S. Biosynthetic effects on the stable carbon isotopic compositions of algal lipids: Implications for deciphering the carbon isotopic biomarker record. Geochim. Cosmochim. Acta 1998, 62, 1397-1406. [CrossRef]

36. Volkman, J.K.; Revill, A.T.; Holdsworth, D.G.; Fredericks, D. Organic matter sources in an enclosed coastal inlet assessed using lipid biomarkers and stable isotopes. Org. Geochem. 2008, 39, 689-710. [CrossRef]

37. Zelles, L. Fatty acid patterns of phospholipids and lipopolysaccharides in the characterisation of microbial communities in soil: A review. Biol. Fertil. Soils 1999, 29, 111-129. [CrossRef]

38. Otto, A.; Simpson, M. Degradation and preservation of vascular plant-derived biomarkers in grassland and forest soils from western Canada. Biogeochemistry 2005, 74, 377-409. [CrossRef]

39. Van Dongen, B.E.; Zencak, Z.; Gustafsson, Ö. Differential transport and degradation of bulk organic carbon and specific terrestrial biomarkers in the surface waters of a sub-arctic brackish bay mixing zone. Mar. Chem. 2008, 112, 203-214. [CrossRef]

40. Meyers, P.A.; Ishiwatari, R. The Early Diagenesis of Organic Matter in Lacustrine Sediments; Springer: New York, NY, USA, 1993; pp. 185-209. 
41. Chinese Air Quality On-Line Monitoring Platform. Available online: http://www.aqistudy.cn/historydata/ monthdata.php?city=xiamen (accessed on 12 November 2016).

42. 2003Undergraduates. Characteristic and sources of $n$-alkanes bound to $\mathrm{PM}_{10}$ in the air of Xiamen. J. Xiamen Univ. 2007, 46, 99-102. (In Chinese)

43. Gong, D.Y.; Wang, W.; Yun, Q.; Bai, W.; Guo, Y.; Rui, M. Observed holiday aerosol reduction and temperature cooling over East Asia. J. Geophys. Res. 2014, 119, 6306-6324. [CrossRef]

44. Volkman, J.K.; Barrett, S.M.; Blackburn, S.I.; Mansour, M.P.; Sikes, E.L.; Gelin, F. Microalgal biomarkers: A review of recent research developments. Org. Geochem. 1998, 29, 1163-1179. [CrossRef]

45. Blair, N.; Leu, A.; Muñoz, E.; Olsen, J.; Kwong, E.; Des Marais, D. Carbon isotopic fractionation in heterotrophic microbial metabolism. Appl. Environ. Microb. 1985, 50, 996-1001.

46. McCallister, S.; Bauer, J.E.; Cherrier, J.E.; Ducklow, H.W. Assessing sources and ages of organic matter supporting river and estuarine bacterial production: A multiple-isotope $\left(\delta^{14} \mathrm{C}, \delta^{13} \mathrm{C}\right.$, and $\left.\delta^{15} \mathrm{~N}\right)$ approach. Limnol. Oceanogr. 2004, 49, 1687-1702. [CrossRef]

47. Yan, Y.; Jiang, L.; Liu, H.; Shen, H. Analysis of the monitoring results on flu pathogen over Xiamen during 2004-2013. Chin. Med. Stat. 2014, 5, 369-370. (In Chinese)

48. Sinensky, M. Temperature control of phospholipid biosynthesis in Escherichia coli. J. Bacteriol. 1971, 106, 449-455. [PubMed]

49. Fang, M.; Zheng, M.; Wang, F.; Chim, K.S.; Kot, S.C. The long-range transport of aerosols from northern China to Hong Kong-A multi-technique study. Atmos. Environ. 1999, 33, 1803-1817. [CrossRef]

50. Azevedo, D.D.A.; Moreira, L.S.; Siqueira, D.S.D. Composition of extractable organic matter in aerosols from urban areas of Rio de Janeiro city, Brazil. Atmos. Environ. 1999, 33, 4987-5001. [CrossRef]

51. Tao, S.; Eglinton, T.I.; Montluçon, D.B.; McIntyre, C.; Zhao, M. Diverse origins and pre-depositional histories of organic matter in contemporary Chinese marginal sea sediments. Geochim. Cosmochim. Acta 2016, 191, 70-88. [CrossRef]

52. Tao, S.; Eglinton, T.I.; Montluçon, D.B.; McIntyre, C.; Zhao, M. Pre-aged soil organic carbon as a major component of the yellow river suspended load: Regional significance and global relevance. Earth Planet. Sci. Lett. 2015, 414, 77-86. [CrossRef]

(c) 2017 by the authors; licensee MDPI, Basel, Switzerland. This article is an open access article distributed under the terms and conditions of the Creative Commons Attribution (CC BY) license (http:/ / creativecommons.org/licenses/by/4.0/). 